Olivera B. Radović ${ }^{1}$

Dragana Z. Stanojević

University of Pristina with temporary

Head Office in Kosovska Mitrovica

Faculty of Philosophy, Department of Psychology

Kosovska Mirovica (Serbia)

Oliver M. Tošković ${ }^{3}$

University of Belgrade, Faculty of Philosophy,

Department of Psychology, Belgrade (Serbia)
UDC 316.644:316.752(497.11)"2014"

Original scientific paper

Submitted 26/05/2019

Revised 24/06/2019

Accepted 25/06/2019

doi:10.5937/socpreg53-21692

\title{
VALUES AND SUBJECTIVE WELL-BEING IN CONTEXT OF TRANSITION: DATA FROM SERBIA
}

Abstract: This research explores two main objectives: $1^{\text {st }}$ is to examine whether the Schwartz's value theory (Schwartz et al., 2012) can be applied to the Serbian sample, and $2^{\text {nd }}$ is to examine the intensity and the direction of the relation of those values with cognitive and affective components of subjective well-being in the specific socio-political context, which Serbia as a country in transition represents. The sample includes 412 adults, with the average age of $\mathrm{M}=34.42$ ( $\mathrm{SD}=6.305$ ). The following self-description measures are used: the Portraits Values Questionnaire (PVQ-RR, Schwartz et al., 2012), The Satisfaction with Life Scale (Diener, Emmons, Larsen \& Griffin, 1985), and Serbian Inventory of Affect based on the Positive and Negative Affect Schedule-X (SIAB-PANAS, Novović \& Mihić, 2008). Gathered results demonstrate that the values established by the revised Schwartz's model are adequately organized in our sample. Obtained relations between those values and the subjective well-being components can be regarded as expected and in accordance with the healthy values perspective referring to the relation of values and SWB. Finally, the implications of the obtained results are discussed.

Keywords: values, circular model, well-being, self-determination theory

Personal values are motivational dispositions related to the "desirable trans-situational goals that vary in importance, and serve as guiding principles in the life of a person or other social entity" (Schwartz, 1994, p. 21). Values are "central component of our self and personality" (Schwartz, 2012, p.) and their effects on attitudes and behaviors have been widely investigated during the last few decades. Although there is a body of evidence from psychotherapy literature that personal goals are important factor of personal well-being, there are relatively few researches with object of investigating the relation between personal values conceptualized by the Schwartz's model - as one of most widely used theories of value nowadays and subjective well-being. Furthermore, there are even fewer data dealing with relations between values and subjective well-being in diverse socio-political contexts.

\footnotetext{
1 stulaolivera@yahoo.com

2 dragana_dj2004@yahoo.com

3 otoskovi@gmail.com.
} 
Originated within the field of positive psychology, the concept of subjective well-being (SWB) refers to the "individual cognitive or affective evaluation of one's life" (Diener, Lucas, \& Oshi, 2002, p. 63) and includes three components that represent the concepts' operationalization: "experiencing pleasant emotions, low level of negative moods and high life satisfaction" (Diener et al., 2002, p. 63).

In this paper, we will consider the relationship between personal values and subjective well-being having in mind specifies of the social environment where the relationship is being examined. As we do not have any knowledge on the evaluation of the Schwartz's value theory on our population at the moment, and previous findings show that the Schwartz's circular model of values fits poorly in less developed societies (Bilsky, Janik \& Schwartz, 2011), before considering the relations between the values and the level of personal well-being, we will have to validate whether the data gathered from Serbia match the proposed theoretical value model.

Originally, Schwartz (1992) proposed the theory of the universal content and structure of values with ten distinct motivational types of values, determined by motivational goals and specific principles representing them. Based on the empirical data and conceptual determination of ten basic values, in order to improve the heuristic and predictive power of the model of values, Schwartz recently refined the value differentiation along the continuum and proposed a more fine-tuned model with 19 potentially distinctive values, which are defined in Table 1

Some of the values in the new model have originated from the finer division of earlier widely defined values (e.g. the value of conformity is divided into two values: interpersonal conformity and conformity to rules), whereas certain new values are the ones that lie on a segment of motivational continuum situated between two previously wider values (e.g. new value humility which lies between conformity and benevolence). Multi-dimensional scaling and confirmatory factor analysis of 57 items intended for measuring these values have confirmed the distinctiveness among 19 types of values and postulated the order of values on data with 15 samples in 10 countries (Schwartz et al., 2012). Basic values are organized in two dimensions in the circular motivational continuum that reflects relations of conflicts and compatibility among them. The first dimension of this circular structure contrasts values that emphasize openness to change (self-direction, stimulation) and conservation (conformity, tradition and security), while the second dimension of the value space contrasts self-enhancement (power and achievement) and self-transcendence (universalism and benevolence) (Schwartz, 1992). In the refined theory (Schwartz et al., 2012), hedonism is located between the openness to change and self-enhancement values, face is located between the self-enhancement and conservation values.

Combining the neighboring values from the circle, it is possible to reproduce the original ten values (in the refined theory third level of hierarchical organization), or form different groups of values that are crucial for researching a certain topic. It is possible to distinguish values on dimension personal (openness to change and self-enhancement) or social focus (self-transcendence and conservation), as well as growth, anxiety-free (selftranscendence and openness to change) vs. self-protection, anxiety-avoidance (conservation and self-enhancement) values (Schwartz et al., 2012).

In consideration of the relationship between values and subjective well-being, the most commonly used approach is established on the theory of self-determination by Deci 
and Ryan $(1985,1991,2000)$ where the general, universal relations between certain values and subjective well-being ("healthy" values perspective) are postulated. According to SDT, three basic psychological needs - autonomy, competence and relatedness are universal and must be satisfied in all cultures for people to be optimally healthy (Deci \& Ryan, 2000). Kasser and Ryan (1996) made the distinction between intrinsic and extrinsic values and goals and suggested that they should have a differential significance for well-being. Thus, the values whose motivational goal is to fulfill basic psychological demands are set towards intrinsic satisfaction and "unconditional" subjective well-being in the broad range of highly varied cultures (Deci \& Ryan, 2008).

In line with this approach, Sagiv, Roccas and Hazan (2004) divided Schwartz's values according to their underlying goal - "intrinsic" values are believed to be self-direction, stimulation (demand for autonomy), universalism, benevolence (demand for interconnection) and achievement (demand for competence), while power, security, conformity and tradition are interpreted as the values that represent the "extrinsic" motivation that should be related to higher anxiety and lower welfare. Over the last two decades, evidence has accumulated to show that pursuing the extrinsic goals of money, image, and status is actually associated with lower well-being and greater distress (Kasser, 2014).

However, empirical data provide an imprecise image on "universal" relations between values and subjective well-being (Oishi, Diener, \& Lucas, 1999; Bobowik et al., 2011; Roccas, Sagiv, Schwartz \& Knafo, 2002; Kasser \& Ryan, 1993), i.e. diverse studies offer relatively low and inconsistent relations between certain values and diverse aspects of SWB.

One of the reasons for obtaining inconsistent results lies in the fact that the importance of socio-political context was neglected in the mentioned studies. On one hand, some values do not have the same meanings in different cultures - for example, a goal of conformity may mean belonging to community in Eastern cultures but a lack of autonomy in Western cultures (Schmuck, Kasser \& Ryan, 2000). On the other hand, some goals and values may have different relations with the fulfillment of basic needs cross-culturally and thus would lead to different outcomes regarding subjective well-being.

Kemppainen (2012) investigated how four indicators of well-being - economic hardship, sickness, societal pessimism and social recognition - are distributed across the social structure in European welfare regimes. The author's results show that well-being is to a significant extent conditioned by the position one occupies in the social structure and by the welfare regime one lives in.

Sortheix and Lönnqvist (2014) examined the relations of personal values to life satisfaction using data from 25 European nations. The significance of the effect of the country-level Human Development Index (HDI) as a contextual moderator was tested on the relations between personal values and subjective well-being. Sortheix (2014) differentiates values according to the person-focused dimension (self-enhancement and openness to change) and social-focused values (universalism, benevolence, tradition and conformity) and assumes that, in economically underdeveloped countries, a person-focused values might be a more successful strategy for obtaining well-being, while in more developed societies social-focused values might provide greater satisfaction (Sortheix \& Lönnqvist, 2014).

The results demonstrated that HDI moderated 8 relations out of 10 Schwartz's values and life satisfactions. In all countries, benevolence and hedonism were associated with 
heightened life satisfaction, whereas power and security were related to lower life satisfaction. In low HDI countries (which are similar to Serbia), self-direction, stimulation, and achievement were positively related to life satisfaction, whereas universalism, tradition and conformity were negatively associated with life satisfaction (LF), while those associations are opposite in high HDI countries (Sortheix \& Lönnqvist, 2014).

Similarly, the study conducted by Rijavec, Brdar and Miljković (2011) in Croatia, shows that both intrinsic and extrinsic goals contribute to well-being among college students. Also, as Brdar, Rijavec and Miljković (2009) report, data from Hungary and Macedonia show a similar pattern of relations (Martos, in press, Spasovski, 2009, according to Brdar at all, 2009). Generally, while there is a body of evidence that the extrinsic goals are detrimental to well-being in rich, western countries, it seems that in transitional, less developed countries these goals have positive contribution to well-being.

Serbia's HDI value for 2014 places the country in the high human development category- positioning it at 66 out of 188 countries and territories. Although Serbia has achieved a steady progress on the human development index scale over the years, it is still far behind (positioning 39 out of 46) other European countries (UNDP, 2015). Analysis of Social Progress Index (Porter, Stern and Green, 2015) shows that relative weaknesses (compared with countries with similar GDP per capita) are the availability of affordable housing, health and wellness, personal freedom and choice, tolerance and inclusion.

Although relationship between values and one aspect of SWB - life satisfaction has been investigated in prior communist countries (Soertheix \& Lonnqvist, 2014), Serbia is specific case due to delayed radical economic reforms until late 2000 (end of Milosevic regime), many statehood changes (25 years) with latest, still open conflict with Kosovo, its southern province that proclaimed independence (2008). Serbia's transition is complex, in many ways unique: it has been complicated with military conflicts, deindustrialization, international sanctions, NATO bombing, political instability, with severe economic consequences - increasing poverty and social differentiation, corruption, flourishing of illegal activities, slow economic recovery. During the transitional period (2002-2011), the rate of unemployed citizens dramatically increased - from $13.3 \%$ in 2002 to $23.9 \%$ in 2012 (Šuvaković, 2014). Despite strong (,jobless“) growth, by 2008 real GDP was only $72 \%$ of 1989 level and Serbia has most unfavorable position among all Balkan countries (Uvalic, 2010).

Finaly, Šuvaković $(2014$, p. 345) points out that

"the most of the citizens are transitional losers regarding their material status, which is considerably worse than it used to be before the start of this process, but they are also the losers in the sense that the value system has been completely inverted, the system in which most of them were socialized."

Having the above in mind, our research is based on two main objectives:

To examine whether the values are organized into the redefined Schwartz's structural model in a Serbian sample;

To examine the relations between the values defined by the Schwartz's theory and the cognitive and affective aspects of subjective well-being having on mind socio-political context in Serbia. 
We assumed that, in accordance with the existing research results, the theoretical structure of values will be confirmed on the population sample from Serbia.

Other than showing specifics like process of transition, the analysis of the socio-political context of Serbia in Europe demonstrates that Serbia is characterized by "insecurity, interpersonal distrust and institutional distrust, as well as a wide popularity of "materialistic" values, situating Serbia into the plane of underdeveloped ex-communist societies in transition in the initial stages of democratization" (Pavlović, 2006, p. 247). According to this, we are interested if person focused values would be more powerful strategy for obtaining higher level of SWB in extremely unfavorable social conditions.

Based on previous findings in countries with similar HDI (Sortheix, 2014), we could assume that, self-enhancement values (achievement, but not power) and openness to change values (self-direction, stimulation, hedonism) together with benevolence will be associated with higher level of wellbeing as a way to fulfill basic needs in Serbian society, but not universalism.

The research contribution is observed in evaluating the model values on the nonevaluated sample; i.e., considering the specificities of the social environment. An additional insight will be provided onto the relationships between values and subjective wellbeing in specific socio-political context.

\section{Method}

\section{Sample}

Data were collected during September and October 2014. The sample was constructed using the snowball sampling technique (Goodman, 1961). Respondents were asked to voluntarily fill in the self-report questionnaire, which included a cover letter explaining the purpose and the objective of the research. The sample consisted of 412 respondents, $183(44.4 \%)$ male and 229 (55.6\%) female respondents. Age range was from 20 to 53, with the average respondents' age being $34.42(\mathrm{SD}=6.305)$.

\section{Measures}

Values. Respondents filled in the separate gender-matched Serbian versions of the Schwartz's PVQ-RR (Schwartz et al., 2012). The PVQ-RR includes 57 short descriptions of different people, each describing a goal that is important to the person. Respondents indicated how similar this person is to themselves on the 6 point scale: 1 - not like me at all, 2 - not like me, 3 - a little like me, 4 - moderately like me, 5 - like me, 6 - very much like me. A team of bilinguals (two persons) translated the PVQ-RR from English to Serbian. Schwartz (author of the survey) checked the translations and back-translations (into English) of the questionnaire. This procedure was repeated three times, until everyone agreed that the translated version optimally captured the nuances of each survey item.

Subjective well-being. Life satisfaction refers to the global cognitive assessment of satisfaction with one's life and it is examined using the Satisfaction with Life Scale (SWL: Diener, Emmons, Larsen \& Griffin, 1985). The Satisfaction with Life Scale is a widely used measure of well-being, consisting of five items (e.g., "I am satisfied with my present life"); Cronbach's Alpha in our sample is 0.83 . For measuring the positive 
(PA) - negative affect (NA), i.e., the frequency of experiencing pleasant emotions and unpleasant emotions, the Serbian Affect Inventory, based on PANAS-X (SIAB-PANAS Novović \& Mihić, 2008) is used. Cronbach's Alpha in our sample is for PA scale 0.81, and for NA scale 0.84 .

\section{Statistical Analysis}

Confirmatory factor analysis (CFA). In order to assess the discriminability of 19 values and the optimal indexes for them, we ran confirmatory factor analyses. With 412 respondents, assessing a model with 19 latent variables and 57 value items, it was virtually impossible to be reliable. We, therefore, followed Cieciuch and Schwartz (2012) and ran separate CFAs on four higher order categories of values (self-enhancement, self-transcendence, openness to change, and conservation). We used multiple fit indexes to evaluate the covariance structures of the models: the Comparative Fit Index (CFI), the Root Mean Square Error of Approximation (RMSEA), and the ratio of $\chi 2$ and the number of degrees of freedom (df). We treated CFI values $>.90$ (Bentler, 1990), RMSEA values $<.08$ (Browne \& Cudeck, 1993), and $\chi 2$ /df values from 2 to 5 (Marsh \& Hocevar, 1985; Schumacker \& Lomax, 2004; Wheaton, Muthen, Alwin, \& Summers, 1977) as indicating a reasonable model fit. We performed all analyses with LISREL 9.1.

Multidimensional scaling analyses (MDS). We performed a confirmatory MDS analysis (Borg et al., 2013) to assess the structure of relations among the 19 values. Following Bilsky, Janik, and Schwartz (2011), we specified a starting configuration for the values based on the theorized circular structure of values and used ordinal proximity transformations, Euclidean distances, and z-score transformed items.

Correlation analysis and canonical correlation. Those analyses were used to clarify the relations between values and the cognitive and affective aspects of subjective well-being.

\section{Results}

First we conducted confirmatory factor analysis, separately for every of four higher order factors in order to determine the discriminability of the 19 values. As fit indices we used Chi square ( $\chi 2)$, RMSEA, CFI and $\chi^{2 / d f}$ ratio. Eigures 1-4 represent path diagrams with standardized loading values, for all 4 higher order value factors: Openness, Conservation, Self-enhancement and Self-transcendence.

Table 2 provides the results of the confirmatory factor analyses for every higher order factor: Openness to change (self-direction-thought, self-direction-action, stimulation, hedonism), Self-enhancement (achievement, power-dominance, power-resources, face), Conservation (security-personal, security-societal, tradition, conformity-rules, conformity-interpersonal, humility), and Self-transcendence (benevolence-caring, benevolencedependability, universalism-nature, universalism-concern, universalism-tolerance). As it can be observed, there are satisfactory indicators for every factor: all CFIs are more than 0.90 , demonstrating the satisfactory model fit, RMSEAs are less than 0.05 , and $\chi 2 / \mathrm{df}$ are below 2 .

This analysis only shows that first order 19 values can fit into 4 higher order factors, as theory predicts. But, it cannot confirm that this kind of a model gives the best fit to data. 
One way to test this model more precisely would be to perform one confirmatory analysis on all 19 first order factors, and 4 higher order factors. Unfortunately it was not possible to asses a reliable model with 19 latent variables and 57 value items, on 412 respondents. Therefore, we performed multidimensional scaling, following Bilsky et al. (2011).

Multidimensional scaling. Fig. 5 presents the results of the multidimensional scaling for 57 items. The results indicate that the order of values on the circular continuum corresponds to the theoretically postulated order with several usual deviations. The greatest deviation is the alteration of places between the values universalism and benevolence, as well as interpersonal conformity and humility. Likewise, it is possible to observe that two distinctive spaces can be separated on a value continuum, though humility is placed between two types of conformity. Achievement is closer to hedonism and stimulation. Furthermore, based on the obtained order presented in Fig. 2 and based on the model, it can be observed that 10 original values can be reproduced, and that the 19 values form the same motivational continuum as the original 10. Cronbach's Alpha coefficients for 19 values are as follows: self-direction (thought) - 0,69; self-direction (action) - 0,70; stimulation - 0,70; hedonism - 0.74; achievement - 0,66; power (dominance) - 0,77; power (resources) - 0,77; face - 0,56; security (personal) - 0,53; security (societal) - 0,79; tradition - 0,87 ; conformity (rules) - 0,77; conformity (interpersonal) - 0,67; humility - 0,41 ; universalism (nature) - 0,83; universalism (concern) - 0,65; universalism (tolerance) 0,63 ; benevolence (caring) - 0,74; benevolence (dependability) - 0,77. Cronbach's Alpha coefficients for 10 original values are as follows: for tradition -0.87 ; benevolence -0.86 ; self-direction -0.81 ; universalism -0.80 ; power -0.78 ; hedonism -0.74 ; conformity 0.74 ; security -0.72 ; stimulation -0.70 ; and achievement -0.66 . These coefficients are similar to the average ones reported by Schwartz (2012).

Some basic descriptive measures for 19 value types, calculated according to Schwartz theory, can be found in Table 2 Almost all value dimensions have relatively normal distributions (skewness and kurtosis values are within range -1 to 1). Only benevolence and self -direction dimensions do not have normally distributed values - they have negatively asymmetric (skewness smaller than -1) and leptokurtic distributions (kurtosis larger than 1). So, in our sample, on benevolence and self -direction dimensions we have reduced variability with negative outliers (Table 3). Prior to further analysis, both of those variables were normalized.

Correlation analysis. As perceived in Table 4 there are low, yet significant correlations between life satisfaction and achievement, conformity to rules and universalismtolerance and low negative correlation with face. The positive affect is associated with selfdirection (both -thought and action), stimulation, achievement and benevolence - caring, as well as lower evaluation of power (in relation to resources), humility and interpersonal conformity. The negative affect is associated with power (both dominance and resources), humility and the lower evaluation of benevolence (caring and dependability) and achievement.

Since Pearson correlations reveal only individual relations between pairs of variables, and value dimensions are interrelated, we performed the canonical correlation analysis in order to test global relation between values on one side and subjective well-being measures on the other side. Analysis revealed two significant canonical factors and we used the correlation value of 0.3 as a criterion for variable inclusion in the factor structure Table 5. 
Based on factor loadings (correlations between each variable and canonical factor), we can see that one dimension (canonical factor) shows positive relation between some value dimensions (self-direction - thought and action, hedonism, achievement, universalism - tolerance and concern, benevolence - caring and dependability) with positive affect and life satisfaction, and negative relation between those values with negative affect. It can be interpreted as the tendency of people with higher sense of well-being to give more importance to anxiety free values that represent growth.

However, the other dimension (canonical factor) shows positive relation between some value dimensions (power - dominance, humility) with primary negative affect and (in the lower level) with life satisfaction, and negative relation between those values and positive affect. Value dimension benevolence - dependability has reverse correlation direction, it shows negative relation with life satisfaction and negative affect, and positive relation with positive affect.

\section{Discussion}

The research has two main objectives: to examine whether the values postulated by the Schwartz's theory, in the sample from Serbia, correlate in the same manner as in the original research, as well as to examine the relations between those values and subjective well-being components - life satisfaction, positive and negative affect. The first objective was realized utilizing two adequate statistic approaches - confirmatory factor analysis and multidimensional scaling.

The data obtained using those two methods demonstrate that the value structure predicted by the Schwartz's theory is reproduced in our sample as well. By confirmatory factor analysis we tested one-by one higher order value factors, in separate models, and gained satisfactory fit indices, showing that values can be grouped into higher order dimension as theory predicts. In this way it was possible to isolate four higher order factors, and we can argue, in some sense, that four higher order value factors models are adequate. Similar results are obtained from other countries as well (Schwartz et al., 2012). Likewise, the multidimensional scaling illustrates that the value order on circular continuum corresponds to the theoretically postulated order (Schwartz, 2014), with several deviations. The greatest deviation is the position replacement of the values universalism and benevolence, which is also noted in the report by Schwartz et al. (2012). Furthermore, interpersonal conformity and humility also switched places, which are again compatible to previous reports (Schwartz et al., 2012). Even though there are samples, according to the report by Schwartz et al. (2012), where these two values are not clearly differentiated, in our sample two separate places on the value continuum are divided, though humility is situated between these two types of conformity. This order benefits the Schwartz's thesis that it appears as if these values have multiple motivation: both placing other people's interests before one's own (humility) and avoiding hurting others (interpersonal conformity) are based on the care and protection of oneself and others. Achievement is somewhat closer to hedonism and stimulation, and further away from power. As already remarked, achievement is also a value most closely related to SWB in Serbia. Since the values that are less abstract and less related to the self-concept in MDS graph are the ones closer to the center (Schwartz et al., 2012), it appears that the motivation existing in the basis of achievement 
is closely related to the need for autonomy and competence which are in this context important for achieving the basic demands.

Canonical correlation analysis indicates positive relation between value dimensions that represent "anxiety free" values - self-direction (thought and action), universalism (tolerance and concern), benevolence (caring and dependability), hedonism, achievement, with positive affect and life satisfaction. The importance of those values for life satisfaction and positive affect is understandable as they represent so-called "healthy" values, as we will discuss further. In other studies, achievement is also emphasized as a significant life satisfaction factor in the countries with similar socio-economic status - post communist European countries (Sortheix, 2014) and Iran (Joshanloo \& Ghaedi, 2009).

On the other hand, there are positive relations between power - dominance and humility with primary negative affect and (in the lower level) with life satisfaction, and negative relation between those values and positive affect. This finding reveals an interesting relation, since it shows that higher life satisfaction can go together with negative affect, and lower positive affect - with persons who tend to recognize one's insignificance in the larger scheme of things but tend to exercise control over people.

Although it is usual finding that life satisfaction is in line with positive affect, it seems that different results are not uncommon. To support this assumption, we can mention that some earlier multi-method studies show that affect and life satisfaction reports can be empirically distinct (Lucas, Diener, \& Suh, 1996; Luhmann, Hawkley, Eid, \& Cacioppo, 2012). Also, there are some conceptual distinctions between those two constructs which could be emphasized (cognitive and emotional nature of constructs, for example). Although there is some relationship between the two, researchers consistently argued that life satisfaction is more than just the sum of affective experiences (Hofmann, Luhmann, Fisher, Vohs, \& Baumeister, 2014).

Considering the characteristics of the social context that the Serbian society represents, the obtained relations were partly expected. Namely, according to the analyses of the position of Serbia in Europe, the country belongs to the group of low HDI countries, characterized by the communist past, low gross national income, transition, and initial democratization, all of which imply massive structural changes leading towards inequality, instability and social differentiation. As a consequence, there is a large percentage of people seeking materialistic goals with the articulated sense of the lack of control over one's life (Pavlović, 2006).

Even the value ranking (Table 2) demonstrates that the values having personal autonomy and competence (high evaluation of self-direction) in their core, apart from the traditionally high level of importance for the well-being of one's closest family members, are among the most accepted values in the society. Likewise, in a more recent study (Radović, 2014), on a sample of 773 citizens of Serbia, material condition, ambition and leadership (the values conceptually very similar to the Schwartz's achievement values) displayed a significant relation with all three components of subjective well-being. In a relatively poor society which Serbia represents today, where the satisfaction of basic needs - food, clothing, health service, education, etc. - is not a presupposition for everyone, it seems that the feeling of subjective well-being is primarily related to those values whose indirect goal is in essence to provide basic needs for economic and psychological safety of oneself and the closest family members. 
In essence, the valuing benevolence, hedonism, achievement, self-direction, universalism, and not power demonstrate the expected associations with subjective well-being in accordance with the previous research reports (Sagiv \& Schwartz, 2000, Bobowik at all, 2011) and in line with inferences based on self-determination theory.

Beside this, when considering the values of universalism, previous studies of low HDI countries (Sortheix, 2014) are directed towards the conclusion that this value is not widely accepted in the transition countries, mostly due to the described socio-political characteristics in the society; hence, in these societies, their relationship with SWB is not the same as in the developed economies. As Sortheix (2014) explains, it appears that there is a certain level of social development that is necessary to be reached in order for the universalism values to accomplish a positive relation with subjective well-being. Our finding showed opposite relation in sense that values that represent self-transcendence can be important resource for dealing with unfavorable life conditions.

Beside striving to autonomy, taking control over one's life, achieving personal success through demonstrating competence, philanthropy and care for others lead towards satisfying the basic psychological needs and thus higher level of SWB. The values that are directed towards personal sphere - independence and pleasure together with devotion to welfare of close people and tolerance and understanding for all people leads to positive outcomes for personal SWB, even in described social surrounding as today Serbia represent. As Trotsuk (2019) quotes: "if people consider themselves free to choose and control their lives, they are happier than people without such freedoms but with much higher living standards (Freedom in the world, 2010) ".

Finally, certain limitations to the research have to be mentioned, since they are of some importance for the generalization of the obtained results. These are primarily methodological and related to the sample size and a moderately larger number of male respondents. However, the majority of similar researches have been conducted on a relatively similar respondents' range, and there are not enough reliable data in the literature suggesting that the value models are significantly different between male and female respondents. Nevertheless, while planning some future research, this fact may be useful to consider and hence avoid possible concerns related to the reliability of the obtained data.

\section{Conclusion}

The results obtained in this research reveal that the Schwartz's value model can be applied on a sample of adult population from Serbia as well. The components of subjective well-being are related to appropriate values, as it could have been partly expected, having in mind social context in which relationship between values and subjective well-being has been investigated. Our results speak in favor of the "healthy value perspective", even in unfavorable social environment which the Serbian society today represents 


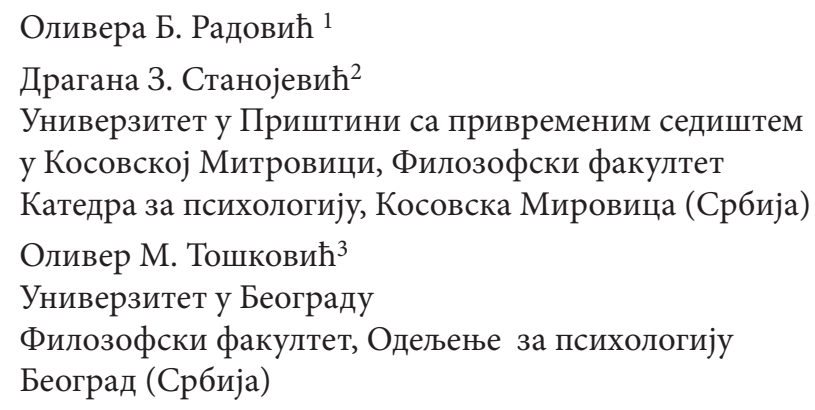

\title{
ВРЕДНОСТИ И СУБЈЕКТИВНА ДОБРОБИТ У КОНТЕКСТУ ТРАНЗИЦИЈЕ: ПОДАЦИ ИЗ СРБИЈЕ
}

\author{
(Превоg In Extenso)
}

Сажетак: Ово истраживање је имало два основна циља: (1) испитати да ли се Шварцов модел вредности (Schwartz et al., 2012) репликује и на српском узорку, и (2) испитати интензитет и смер повезаности тих вредности са когнитивном и афективном компонентом субјективне добробити у специфичном социјалнополитичком контексту који Србија, као земља у транзицији, представља. Узорком је обухваћено 412 одраслих испитаника, просечног узраста $\mathrm{M}=34,42$ ( $\mathrm{SD}=6,305)$. Користили смо следеће самоописне мере: PVQ-RR (Schwartz, et al. 2012), скалу задовољства животом (Diener, Emmons, Larsen \& Griffin, 1985) и SIAB-PANAS (Novović, Mihić, 2008). Добијени резултати показују да се вредности постулиране ревидираним Шварцовим моделом адекватно распоређују и на нашем узорку. Добијене корелације између тих вредности и компоненти субјективне добробити могу се сматрати очекиваним и у складу су са перспективом „здравих вредности” о односу вредности и субјективне добробити. На крају, дискутоване су импликације добијених резултата.

Кључне речи: вредности, кружни модел, субјективна добробит, теорија самоодрећња

Личне вредности су мотивационе диспозиције у вези са „пожељним трансситуационим циљевима различите важности који служе као усмеравајући принципи у животу особе или другог друштвеног ентитета“" (Schwartz, 1994, str. 21). Вредности су „централна компонента нашег селфа и личности“ (Schwartz, 2012, str.) и њихови ефекти на ставове и понашања су широко истраживани током последњих неколико деценија. Иако у литератури о психотерапији постоји мноштво доказа да су лични циљеви важан фактор личне добробити, релативно је мало истраживања чији је циљ испитивање односа између личних вредно-

\footnotetext{
1 stulaolivera@yahoo.com

2 dragana_dj2004@yahoo.com

3 otoskovi@gmail.com.
} 
сти концептуализованих Шварцовим моделом - једном од најчешће коришћених теорија у данашње време, и субјективне добробити. Штавише, још је мање података о односима између вредности и субјективне добробити у различитим друштвено-политичким контекстима.

Настао у области позитивне психологије, концепт субјективне добробити (SD) се односи на „индивидуалну когнитивну и афективну евалуацију сопственог живота“ (Diener, Lucas, \& Oshi, 2002, str. 63) и укључује три компоненте које представљају операционализацију појмова: „висок ниво задовољства животом, висок ниво доживљавања пријатних и низак ниво доживљавања негативних емоција“ (Diener et al., 2002, str. 63).

У овом раду ћемо размотрити однос између личних вредности и субјективне добробити имајући у виду специфичности друштвене средине у којој се овај однос испитује. Пошто у овом тренутку немамо сазнања о потврди Шварцове теорије вредности на нашој популацији, а претходни налази показују да Шварцов кружни модел вредности слабо одговара мање развијеним друштвима (Bilsky, Janik \& Schwartz, 2011), пре разматрања односа између вредности и нивоа личне добробити мораћемо да проверимо да ли подаци прикупљени у Србији одговарају предложеном теоријском моделу вредности.

Шварц (Schwartz, 1992) је првобитно предложио теорију универзалног садржаја и структуре вредности са десет различитих мотивационих типова вредности одређених мотивационим циљевима и специфичним принципима који их представљају. На основу емпиријских података и концептуалног одређења десет основних вредности, како би се побољшала хеуристичка и предиктивна моћ модела вредности, Шварц је недавно усавршио диференцијацију вредности дуж континуума и предложио ревидирани модел са 19 потенцијално различитих вредности, дефинисаних у Габели 1

Неке од вредности у новом моделу потичу од финије поделе вредности које су раније биле широко дефинисане (нпр. вредност конформизам је подељена на две вредности: конформизам у међуљудским односима и конформизам у односу на правила), док су неке нове вредности оне које леже на сегменту мотивационог континуума између две вредности које су раније биле шире дефинисане (нпр. нова вредност понизност која се налази између конформизма и човекољубља). Мултидимензионално скалирање и конфирмативна факторска анализа 57 ставки намењених мерењу ових вредности потврдили су и дистинктивност 19 различитих вредности и постулирани поредак вредности на подацима са 15 узорака у 10 земаља (Schwartz et al., 2012). Основне вредности су организоване у две димензије у кружном мотивационом континууму који одражава односе конфликата и компатибилности међу њима. Прва димензија ове кружне структуре супротставља вредности које наглашавају отвореност за промену (самоусмерење, стимулација) и очување постојећег стања (конформизам, традиција и сигурност), док друга димензија вредносног простора супротставља самоусавршавање (моћ и постигнуће) и самопревазилажење (универзализам и човекољубље) (Schwartz, 1992). У ревидираној теорији (Schwartz et al., 2012), хедонизам се налази између отворености за промену и вредности самоусавршавања, имиџ се налази између вредности самоусавршавања и очувања постојећег стања. 
Комбиновањем суседних вредности из круга могуће је репродуковати десет изворних вредности (трећи ниво хијерархијске организације у ревидираној теорији) или обликовати различите групе вредности које су кључне за истраживање одређене теме. Могуће је разликовати вредности на димензији личног фокуса (отвореност према промени и самоусавршавање) или са друштвеним фокусом (самопревазилажење и очување), као и вредности раста, „слободне од анксиозности“ (самопревазилажење и отвореност за промене) насупрот вредностима самозаштите, „избегавања анксиозности“ (очување и самоусавршавање) (Schwartz et al., 2012).

При разматрању односа између вредности и субјективне добробити најчешће коришћен приступ полази од теорије самодетерминације Деција и Рајана (Deci \& Ryan, 1985, 1991, 2000), у оквиру које се постулирају општи, универзални односи између одређених вредности и субјективне добробити (перспектива „здравих“ вредности). Према теорији самодетерминације, три основне психолошке потребе - аутономија, компетентност и повезаност су универзалне и морају бити задовољене у свим културама како би људи били оптимално здрави (Deci \& Ryan, 2000). Касер и Рајан (Kasser \& Ryan, 1996) направили су разлику између интринзичких и екстринзичких вредности и циљева и предложили да би оне могле имати различито значење за добробит. Дакле, вредности чији је мотивациони циљ да испуне основне психолошке захтеве усмерене су према интринзичком задовољству и „безусловној“ субјективној добробити код врло разноликих култура (Deci \& Ryan, 2008).

У складу са овим приступом, Сагив, Рокас и Хазан (Sagiv, Roccas, Hazan, 2004) су поделили Шварцове вредности према њиховом основном циљу - верује се да су вредности самоусмерење, стимулација (потреба за аутономијом), универзализам, човекољубље (потреба за повезаношћу) и постигнуће (потреба за компетенцијом) „интринзичке“, док се моћ, сигурност, конформизам и традиција тумаче као вредности које представљају „екстринзичку“ мотивацију која је у вези са већом анксиозношћу и нижом добробити. Током последње две деценије, прикупљени су докази који показују да је остваривање екстринзичних циљева у виду новца, имиџа и статуса у вези са нижом добробити и већим стресом (Kasser, 2014).

Међутим, емпиријски подаци нису пружили прецизну слику о „универзалним“ односима између вредности и субјективне добробити (Oishi, Diener, \& Lucas, 1999; Bobowik et al., 2011; Roccas, Sagiv, Schwartz \& Knafo, 2002; Kasser \& Ryan, 1993), тj. у различитим студијама добијене су релативно ниске и неконзистентне корелације између одређених вредности и различитих аспеката субјективне добробити.

Један од разлога за добијање неконзистентних резултата може бити у чињеници да је у поменутим студијама занемарена важност социо-политичког контекста. С једне стране, неке вредности немају исто значење у различитим културама - на пример, конформизам може значити припадност заједници код источних култура, али недостатак аутономије код западних култура (Schmuck, Kasser \& Ryan, 2000). C друге стране, код различитих култура неки циљеви и вредности могу да бити у другачијем односу са испуњењем основних потреба и тако могу довести до различитих исхода у погледу субјективне добробити.

Кемпајнен (Kemppainen, 2012) је истраживао како су четири индикатора социјалног (не)благостања - економске тешкоће, болест, друштвени песими- 
зам и друштвено признање - распоређени по друштвеној структури у европским социјалним режимима. Резултати овог аутора показују да је благостање у значајној мери условљено позицијом у социјалној структури и режимом социјалног благостања у коме живимо.

Сортејсова и Лонквист (Sortheix and Lönnqvist, 2014) испитивали су утицај личних вредности на задовољство животом користећи податке из 25 европских земаља. Значај учинка индекса хуманог развоја (Human Development Index-HDI) на нивоу држава као контекстуалног модератора тестиран је на односима личних вредности и субјективне добробити. Сортејсова (Sortheix, 2014) разликује вредности према димензији оријентисаној ка особи (самоусавршавање и отвореност за промене) и оријентисаној ка друштву (универзализам, човекољубље, традиција и конформизам) и претпоставља да, у економски неразвијеним земљама, вредности фокусиране на особу могу бити успешнија стратегија за остваривање добробити, док у развијенијим друштвима вредности фокусиране на друштво могу довести до већег задовољства (Sortheix and Lönnqvist, 2014).

Резултати су показали да је индекс HDI модерирао 8 од 10 односа Шварцових вредности и задовољства животом. У свим земљама, човекољубље и хедонизам били су у вези са већим задовољством животом, док су моћ и сигурност биле у вези са мањим задовољством животом. У земљама у којима је индекс HDI низак (које су сличне Србији), вредности самоусмерење, стимулација и постигнуће су позитивно утицале на задовољство животом, док су вредности универзализам, традиција и конформизам биле у негативној вези са задовољством животом, док су те асоцијације обрнуте у земљама у којима је индекс HDI висок (Sortheix and Lönnqvist, 2014).

Слично томе, истраживање које су спровели Ријавец, Брдар и Миљковић у Хрватској (Rijavec, Brdar and Miljković, 2011) показује да и интринзички и екстринзички циљеви доприносе добробити студената. Такође, како саопштавају Брдар, Ријавец и Миљковић (Rijavec, Brdar and Miljković, 2009), подаци из Мађарске и Македоније показују сличан образац односа (Martos, у штампи, Spasovski, 2009, према Brdar et al., 2009). Генерално, иако постоји читав низ доказа да су екстринзички циљеви штетни за добробит у богатим, западним земљама, чини се да у мање развијеним земљама, које су у транзицији, ови циљеви позитивно доприносе добробити.

Вредност индекса HDI за Србију за 2014. годину сврстава земљу у категорију високог развоја - позиционира је на 66. место од 188 земаља и територија. Иако је Србија током година остварила стабилан напредак у погледу индекса хуманог развоја, она је још увек далеко иза (39 од 46 позиционираних) других европских земаља (UNDP, 2015). Анализа индекса друштвеног напретка (Porter, Stern, Green, 2015) показује да се релативне слабости (у поређењу са земљама са сличним БДП-ом по глави становника) тичу доступности приступачних стамбених јединица, здравља и добростања, личних слобода и избора, толеранције и инклузије.

Иако је однос између вредности и једног аспекта субјективне добробити - задовољства животом, био проучаван у бившим комунистичким земљама (Soertheix \& Lonnqvist, 2014), Србија је специфичан случај због одложених радикалних економских реформи до краја 2000. године (крај Милошевићевог режи- 
ма), многих промена државности (током последњих 25 година) са последњим, и даље отвореним сукобом око Косова, њене јужне покрајине која је прогласила незави-сност (2008). Транзиција Србије је сложена, на много начина јединствена: закомпликована је војним сукобима, деиндустријализацијом, међународним санкцијама, НАТО бомбардовањем, политичком нестабилношћу, са озбиљним економским последицама - све већим сиромаштвом и социјалним раслојавањем, корупцијом, процватом незаконитих активности, спорим економским опоравком. Током транзиционог периода (2002-2011), стопа незапослености грађана драстично се повећала - са 13,3\% у 2002. на 23,9\% у 2012. години (Šuvaković, 2014). Упркос снажном („незапосленом“) расту, до 2008. године реални БДП био је само $72 \%$ нивоа из 1989. године, а Србија има најнеповољнији положај међу свим балканским земљама (Uvalić, 2010).

Коначно, Шуваковић (Šuvaković, 2014, str. 345) истиче да су

„већина грађана транзициони губитници у погледу њиховог материјалног статуса који је знатно лошији него пре отпочињања овог процеса, али су такође губитници и у том смислу што је систем вредности потпуно изокренут у односу на систем у којем је већина њих социјализована."

Имајући у виду горе наведено, наше истраживање има два главна циља:

1. Испитати да ли се вредности организују у ревидирани Шварцов структурни модел и на узорку из Србије;

2. Испитати односе између вредности дефинисаних Шварцовом теоријом и когнитивних и афективних аспеката субјективне добробити, имајући у виду социополитички контекст у Србији.

Претпоставили смо да ће, у складу са постојећим резултатима истраживања, теоријска структура вредности бити потврђена на узорку становништва из Србије.

Осим приказивања специфичности као што је процес транзиције, анализа друштвено-политичког контекста Србије у Европи показује да Србију карактерише „несигурност, међуљудско и институционално неповерење, као и широка популарност ,материјалних“ вредности, што смешта Србију у раван са неразвијеним бившим комунистичким друштвима у транзицији и у почетним фазама демократизације“ (Pavlović, 2006, str. 247). Према томе, интересује нас да ли би вредности фокусиране на личност биле моћнија стратегија за остваривање вишег нивоа субјективне добробити у изузетно неповољним социјалним условима.

На основу досадашњих налаза у земљама са сличном вредношћу индекса HDI (Sortheix, 2014), могли бисмо да претпоставимо да ће вредности самоусавршавања (постигнуће, али не и моћ) и вредности отворености за промену (самоусмерење, стимулација, хедонизам) заједно са човекољубљем бити у вези са вишим нивоом добробити, јер ове вредности воде задовољавању основних психолошких потреба у описаном контекту какав представља српско друштво, што не важи за универзализам.

Допринос истраживања видимо у томе што ће се проверити вредност модела на узорку на којем није провераван, те ће се, с обзиром на особености социјалног окружења дати додатни увид у односе између вредности и субјективне добробити у специфичном друштвено-политичком контексту. 


\section{Метод}

Узорак

Подаци су прикупљени током септембра и октобра 2014. године. Узорак је конструисан коришћењем технике узорковања по принципу грудве снега (Goodman, 1961). Испитаници су замољени да добровољно попуне самоописни упитник који је садржао и пропратно писмо, објашњење сврхе и циља истраживања. Узорак се састојао од 412 испитаника, 183 (44,4\%) мушког и 229 (55,6\%) женског пола. Распон година је од 20 до 53, а просечна старост испитаника је 34,42 године (SD =6.305).

\section{Mepe}

Вреgносиич. Испитаници су попуњавали српске верзије Шварцовог упитника PVQ-RR (Schwartz et al., 2012), прилагођене полу испитаника. Упитник PVQRR садржи 57 кратких описа различитих људи, од којих сваки описује циљ који је важан особи. Испитаници су на шестостепеној скали навели колико је ова особа слична њима: 1 - није као ја уопште, 2 - није као ја, 3 - мало попут мене, 4 - умерено као ја, 5 - као ја, 6 - врло много као ја. Тим од две особе које говоре оба језика превео је упитник PVQ-RR са енглеског на српски језик. Шварц (аутор упитника) је проверио превод упитника и повратни превод (на енглески). Ова процедура је поновљена три пута, док се сви нису сложили да преведена верзија веродостојно преноси смисао сваке ставке упитника.

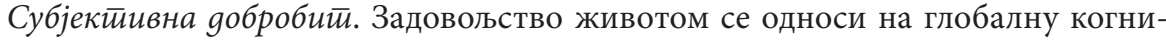
тивну процену задовољства животом и испитивана је преко скале задовољства животом (Satisfaction with Life Scale-SWL) (Diener, Emmons, Larsen \& Griffin, 1985). Скала задовољства животом је широко распрострањена мера добробити која се састоји од пет ставки (нпр. „Задовољан сам својим садашњим животом“); Кромбахова алфа у нашем узорку је 0,83. За мерење позитивног афекта (PA) и негативног афекта (NA), тј. учесталости доживљавања пријатних емоција и непријатних емоција, коришћен је српски инвентар афеката (Serbian Affect Inventory), заснован на упитнику PANAS-X (SIAB-PANAS Novović \& Mihić, 2008). Кромбахова алфа у нашем узорку за скалу PA је 0,81 , а за скалу NA 0,84.

\section{Статистичка анализа}

Конфирматиорна фактиорска анализа (Confirmatory factor analysis - CFA). Да би се проценила дискриминативност 19 вредности и оптимални индекси за њих, извршена је конфирматорна факторска анализа. Са 412 испитаника, било је практично немогуће остварити поузданост процењујући модел са 19 латентних променљивих и 57 вредносних ставки. Стога смо следили Сијакијуча и Шварца (Cieciuch and Schwartz, 2012) и извели смо одвојене CFA анализе за четири категорије вредности вишег реда (самоусавршавање, самопревазилажење, отвореност за промене и очување). Да би се утврдио фит модела, коришћени су следећи индекси фита: CFI (Comparative Fit Index), RMSEA (Root Mean Square Error of Approximation), и количник $\chi 2$ и броја степена слободе (df). Третирали смо вредности CFI > 0,90 (Bentler, 1990), вредности RMSEA <.08 (Browne \& Cudeck, 1993), и вредности $\chi 2 / \mathrm{df}$ од 2 до 
5 (Marsh \& Hocevar, 1985; Schumacker \& Lomax, 2004; Wheaton, Muthen, Alwin, \& Summers, 1977) као показатеље прихватљивог фита модела. Све анализе смо обавили помоћу софтвера LISREL 9.1.

Мулиичиимензионално скалиране (Multidimensional scaling - MDS). Извршили смо конфирматорну MDS анализу (Borg et al., 2013) да бисмо проценили структуру односа између 19 вредности. Следећи Билског, Јаника и Шварца (Bilsky, Janik, Schwartz, 2011), одредили смо почетну конфигурацију за вредности засновану на теоријској кружној структури вредности, користили ординалну трансформацију проксимитета, Еуклидске удаљености и нормализовано одступање (z-score).

Корелациона анализа и каноничка корелаиија. Ове анализе су коришћене за разјашњење односа између вредности и когнитивних и афективних аспеката субјективне добробити.

\section{Резултати}

Прво смо извршили конфирмативну факторску анализу за сваки од четири фактора вишег реда засебно како бисмо утврдили дискриминативност 19 вредности. Као индексе фитовања користили смо Хи квадрат ( $\chi 2)$, RMSEA, RMSEA и количник $\chi 2 / \mathrm{df}$. Слике 1-4 представљају дијаграме пута са стандардизованим вредностима оптерећења за сва 4 фактора вредности вишег реда: отвореност, очување, самоусавршавање и самопревазилажење.

У Габели 2 приказани су резултати конфирматорних факторских анализа за сваки фактор вишег реда: Отвореност за промене (самоусмерење-мисао, самоусмерење-делање, стимулација, хедонизам), Самоусавршавање (постигнуће, моћ-доминација, моћ-ресурси, имиџ), Очување (сигурност-лична, сигурностдруштвена, традиција, конформизам-правила, конформизам-међуљудски, понизност), и Самопревазилажење (човекољубље-брижност, човекољубље-поузданост, универзализам-природа, универзализам-брига, универзализам-толеранција). Као што се може приметити, постоје задовољавајући показатељи за сваки фактор: све вредности индекса CFI су веће од 0,90, указујући на задовољавајући модел, вредности RMSEA су мање од 0,05 , а вредности $\chi 2 / \mathrm{df}$ су испод 2.

Ова анализа показује само да се 19 вредности првог реда може уклопити у 4 фактора вишег реда, као што теорија предвиђа. Међутим, она не може да потврди да ова врста модела најбоље одговара подацима. Један од начина да се овај модел прецизније тестира је да се изврши једна конфирматорна анализа свих 19 фактора првог реда и 4 фактора вишег реда. Нажалост, није било могуће проценити поузданост модела са 19 латентних променљивих и 57 вредносних ставки на 412 испитаника. Стога смо извршили мултидимензионално скалирање, следећи Билског и сараднике (Bilsky et al., 2011).

Мулийдимензионално скалиране. Слика 5 приказује резултате мултидимензионалног скалирања 57 ставки. Резултати указују да редослед вредности на кружном континууму одговара теоријски постулираном поретку са неколико уобичајених одступања. Највеће одступање је замена места вредности универзализма и човекољубља, као и конформизма у међуљудским односима и понизности. Такође, могуће је уочити да се на вредносном континууму издвајају два одвојена простора, 
али се понизност смешта између два типа конформизма. Постигнуће је ближе хедонизму и стимулацији. Штавише, на основу добијеног распореда приказаног на Слици 2 и на основу модела, може да се приметити да је могуће репродуковати 10 оригиналних вредности и да 19 вредности формира исти мотивациони континуум као што то чине оригиналних 10. Кромбахови алфа коефицијенти за 19 вредности су следећи: самоусмерење (мисао) - 0,69; самоусмерење (делање) - 0,70; стимулација - 0,70; хедонизам - 0,74; постигнуће - 0,66; моћ (доминација) - 0,77; моћ (ресурси) 0,77 ; имиџ - 0,56; сигурност (лична) - 0,53; сигурност (друштвена)- 0,79; традиција - 0,87; конформизам (правила) - 0,77; конформизам (међуљудски) - 0,67; понизност - 0,41; универзализам (природа) - 0,83; универзализам (брига) - 0,65; универзализам (толеранција) - 0,63; човекољубље (брижност) - 0,74; човекољубље (поузданост) - 0,77. Кромбахови алфа коефицијенти за 10 оригиналних вредности су следећи: за традицију - 0,87; човекољубље - 0,86; самоусмерење - 0,81; универзализам - 0,80; моћ - 0,78; хедонизам - 0,74; конформизам - 0,74; сигурност - 0,72; стимулација - 0,70; и постигнуће - 0,66. Ови коефицијенти су слични просечним вредностима које је објавио Шварц (Schwartz, 2012).

Неке основне дескриптивне мере за 19 типова вредности израчунатих према Шварцовој теорији могу се наћи у Табели 2 Готово све димензије вредности имају релативно нормалну расподелу (вредности скјунес и куртозис су у распону од -1 до 1). Само димензије човекољубља и самоусмерења немају нормално расподељене вредности - оне имају негативно асиметричну (асиметричност мању од -1) и лептокуртску расподелу (куртозис већи од 1). Дакле, у нашем узорку, на димензијама човекољубља и самоусмерења смањили смо варијабилитет искључивањем негативних „outliear“- a. (Табела 3). Пре даље анализе, обе ове променљиве су нормализоване.

Корелащиона анализа. Као што се види у абелич постоје ниске, али значајне корелације између задовољства животом и постигнућа, конформизма са правилима и универзалности-толеранције и ниска негативна корелација са имиџом. Позитиван афекат се везује за самоусмерење (мисли и делање), стимулацију, постигнуће и човекољубље - брижност, као и нижу процену моћи (у односу на ресурсе), понизности и конформизма у међуљудским односима. Негативан афекат је у вези са моћи (доминацијом и ресурсима), понизношћу и нижом оценом човекољубља (брижности и поузданости) и постигнућа.

Будући да Пирсонове корелације откривају само појединачне односе између парова променљивих, а вредности димензија су међусобно повезане, извршили смо каноничку корелациону анализу како бисмо тестирали глобалну везу између вредности, с једне стране, и мера субјективне добробити, с друге стране. Анализом су откривена два значајна каноничка фактора и коришћена је вредност корелације од 0,3 као критеријум за укључивање променљиве у факторску структуру (Табела 5)

На основу факторских оптерећења (корелација између сваке променљиве и каноничког фактора), можемо видети да једна димензија (канонички фактор) показује позитиван однос између неких вредносних димензија (самоусмерење - мисао и делање, хедонизам, постигнуће, универзализам - толеранција и брига, човекољубље - брига и поузданост) и позитивног афекта и задовољства животом, и негативан однос између тих вредности и негативног афекта. То се може тумачити 
као тенденција људи са вишим осећајем добробити да придају већу важност вредностима „раста“, „слободним од анксиозности“.

Друга димензија (канонички фактор), међутим, показује позитиван однос између неких вредносних димензија (моћ - доминација, понизност) и првенствено негативног афекта и (на нижем нивоу) задовољства животом, и негативан однос између тих вредности и позитивног афекта. Вредност димензије човекољубље - поузданост има супротан смер релације, показује негативан однос са задовољством животом и негативним афектом, и позитиван однос са позитивним афектом.

\section{Дискусија}

Истраживање је имало два основна циља: да испита да ли су вредности постулиране Шварцовом теоријом, на узорку из Србије, организоване на исти начин као и у оригиналном истраживању, као и да испита односе између тих вредности и компоненти субјективне добробити - задовољства животом, позитивним и негативним афектом. Први циљ је остварен коришћењем два одговарајућа статистичка приступа - конфирматорном факторском анализом и мултидимензионалним скалирањем.

Подаци добијени коришћењем ове две методе показују да се вредносна структура предвиђена Шварцовом теоријом репродукује и на нашем узорку. Факторском анализом потврдили смо један по један фактор вредности вишег реда, у одвојеним моделима, и добили задовољавајуће индексе фита, показујући да се вредности могу груписати у димензију вишег реда како то предвиђа теорија. На овај начин било је могуће изоловати четири фактора вишег реда, и можемо на неки начин тврдити да су четири модела фактора вишег реда адекватна. Слични резултати су добијени и у другим земљама (Schwartz et al., 2012). Слично томе, мултидимензионално скалирање илуструје да редослед вредности на кружном континууму одговара теоријски постављеном поретку (Schwartz, 2014), са неколико одступања. Највеће одступање је замена позиција вредности универзализма и човекољубља, што је забележено и у извештају Шварца и сарадника (Schwartz et al., 2012). Штавише, конформизам у међуљудским односима и понизност такође су заменили места, што је опет компатибилно са претходним извештајима (Schwartz et al., 2012). Иако, према извештају Шварца и сарадника (Schwartz et al., 2012), постоје узорци где ове две вредности нису јасно диференциране, у нашем узорку заузимају два одвојена места на вредносном континууму, мада се понизност налази између две врсте конформизма.

Овакав распоред говори у прилог Шварцове тезе да изгледа да ове вредности имају вишеструку мотивацију: постављање интереса других изнад сопствених (понизност) и избегавање повреде других (конформизам у међуљудским односима) имају у основи бригу и заштиту и себе и других. Постигнуће је нешто ближе хедонизму и стимулацији, а даље од моћи. Као што је већ напоменуто, у Србији је постигнуће вредност која је најближе повезана са субјективном добробити. Пошто су вредности које су мање апстрактне и које су ближе повезане са селф-концептом на графикону мултидимензионог скалирања ближе центру (Schwartz et al., 2012), чини се да је мотивација која стоји у основи постигнућа ближе повезана са потребом за аутономијом и компетенцијом које су у овом контексту важне за остварење базичних потреба. 
Каноничка корелациона анализа указује на позитивну везу између вредносних димензија које представљају вредности „ослобођене од анксиозности“ - самоусмерење (мисао и делање), универзализам (толеранција и брига), човекољубље (брижност и поузданост), хедонизам, постигнуће са позитивним афектом и задовољством животом. Важност тих вредности за задовољство животом и позитиван афекат је разумљива јер представљају такозване „здраве“ вредности, о чему ћемо даље расправљати. У другим студијама, постигнуће је такође наглашено као значајан фактор задовољства животом у земљама са сличним социо-економским статусом - у посткомунистичким европским земљама (Sortheix, 2014) и Ирану (Joshanloo \& Ghaedi, 2009).

С друге стране, постоји позитиван однос између моћи - доминације и понизности, примарно са негативним афектом и, на нижем нивоу, са животним задовољством, и негативан однос између тих вредности и позитивног афекта. Овај налаз открива занимљиву везу, јер показује да веће задовољство животом може ићи заједно са негативним афектом, а нижим позитивним афектом - код особа које препознају сопствену неважност у већој шеми ствари, али имају тенденцију да врше контролу над људима.

Иако је уобичајено да је задовољство животом позитивно повезано са позитивним афектом, чини се да различити резултати нису неуобичајени. Да бисмо подржали ову претпоставку, можемо поменути да нека ранија мулти-метод истраживања показују да показатељи афеката и задовољства животом могу бити емпиријски независни (Lucas, Diener, \& Suh, 1996; Luhmann, Hawkley, Eid, \& Cacioppo, 2012). Постоје, такође, неке концептуалне разлике између ова два конструкта које се могу нагласити (когнитивна и емоционална природа конструката, на пример). Иако постоји одређена веза између њих, истраживачи доследно тврде да је задовољство животом више од збира афективних искустава (Hofmann, Luhmann, Fisher, Vohs, \& Baumeister, 2014).

Имајући у виду карактеристике друштвеног контекста које представља српско друштво, добијени односи су делимично очекивани. Наиме, према анализама положаја Србије у Европи, земља спада у групу земаља са ниским HDI индексом које карактерише комунистичка прошлост, низак бруто национални доходак, транзиција и почетна демократизација, што подразумева масивне структурне промене које воде ка неједнакости, нестабилности и социјалном раслојавању. Као последица тога, постоји велики проценат људи који трагају за материјалним циљевима са артикулисаним осећајем недостатка контроле над својим животом (Pavlović, 2006).

Чак и рангирање вредности Табела 2 показује да су вредности које у свом језгру носе личну аутономију и компетенцију (висока оцена самоусмерења), осим традиционално високог нивоа важности добробити најближих чланова породице, међу најшире прихваћеним вредностима у друштву. Исто тако, у новијој студији (Radović, 2014), на узорку од 773 грађана Србије, материјално стање, амбиција и лидерство (вредности које су концептуално веома сличне Шварцовом постигнућу) показале су значајну везу са све три компоненте субјективне добробити. У релативно сиромашном друштву које данас представља Србија, где задовољење основних потреба - храна, одећа, здравствене услуге, образовање, итд. - није претпоставка за 
све, чини се да се осећај субјективне добробити првенствено односи на оне вредности чији је индиректни циљ у суштини да обезбеде основне потребе у погледу економске и психолошке безбедности себе и најближих чланова породице.

У суштини, вредновање човекољубља, хедонизма, постигнућа, самоусмерења, универзализма, а не моћи, показује очекиване везе са субјективном добробити, што је у складу са претходним истраживачким извештајима (Sagiv \& Schwartz, 2000, Bobowik at all, 2011) и са закључцима заснованим на теорији самоодређења.

Поред тога, што се тиче вредности универзализма, претходна истраживања земаља са ниским HDI индексом (Sortheix, 2014) усмерена су на закључак да ова вредност није широко прихваћена у земљама у транзицији, углавном због описаних друштвено-политичких карактеристика у друштву; стога, у овим друштвима, њихов однос са субјективном добробити није исти као у развијеним економијама. Као што Сортејсова (Sortheix 2014) објашњава, чини се да постоји одређени ниво друштвеног развоја који је потребан да би се постигло то да вредности универзализма остваре позитиван однос са субјективном добробити. Наш налаз је показао супротан однос, у смислу да вредности које представљају самопревазилажење могу бити важан ресурс за превладавање неповољних животних услова.

Поред тежње ка аутономији, преузимања контроле над животом, постизања личног успеха кроз демонстрирање компетентности, филантропија и брига за друге воде ка задовољавању основних психолошких потреба, а тиме и вишег нивоа субјективне добробити. Вредности које су усмерене ка личној сфери - независност и задовољство заједно са преданошћу добробити блиских људи и толеранцији и разумевању за све људе, доводе до позитивних исхода за личну субјективну добробит, чак и у описаном друштвеном окружењу какво данас представља Србија. Као што то Ирина Тротсук (Trotsuk, 2019) цитира: „ако људи сматрају себе слободним да бирају и контролишу сопствени живот, они су сретнији од људи који немају ту слободу, али имају много виши животни стандард (Freedom in the world, 2010)“.

Коначно, потребно је споменути одређена ограничења истраживања, јер су она од изузетног значаја за генерализацију добијених резултата. Она су примарно методолошка и односе се на величину узорка и умерено већи број мушких испитаника. Међутим, већина сличних истраживања спроведена је на релативно сличном узорку испитаника, а у литератури нема довољно поузданих података који сугеришу да се модели вредности значајно разликују код мушких и женских испитаника. Ипак, приликом планирања неких будућих истраживања, ова чињеница може бити корисна за разматрање и избегавање могућих проблема у вези са поузданошћу добијених података.

\section{Закључак}

Резултати добијени овим истраживањем показују да се Шварцов модел вредности може применити и на узорку одрасле популације из Србије. Компоненте субјективне добробити у вези су са одговарајућим вредностима, што се делимично могло и очекивати имајући у виду друштвени контекст у коме се истражује однос између вредности и субјективне добробити. Наши резултати говоре у прилог „перспективи здравих вредности“ чак и у неповољном друштвеном окружењу које српско друштво данас представља. 


\section{REFERENCES / ЛИTEPATУPA}

Bentler, P. M. (1990). Comparative fit indexes in structural models. Psychological bulletin, 107(2), 238.

Bilsky, W., Janik M., \& Schwartz, S. H. (2011). The Structural Organization of Human Values-Evidence from Three Rounds of the European Social Survey (ESS). Journal of Cross-Cultural Psychology, 42(5) 759-776. doi: 10.1177/0022022110362757

Bobowik, M., Basabe, N., Paez, D., Jimenez, A., \& Bilbao, M. A. (2011). Personal values and well-being among Europeans, Spanish natives and immigrants to Spain: Does the culture matter? Journal of Happiness Studies, 12, 401-419 doi:10.1007/s10902 010-9202-1

Brdar, I., Rijavec, M., \& Miljković, D. (2009). Life Goals And Well-Being: Are Extrinsic Aspirations Always Detrimental To Well-Being? Psihologijske teme, 317-334

Browne, M. W., \& Cudeck, R. (1993). Alternative ways of assessing model fit. Sage focus editions, 154, 136-136.

Cieciuch, J., \& Schwartz, S. H. (2012). The number of distinct basic values and their structure assessed by PVQ-40. Journal of personality assessment, 94(3), 321-328.

Deci, E. L. \& Ryan, R. M. (1985). Intrinsic motivation and self-determination in human behavior. New York: Plenum Press.

Deci, E. L. \& Ryan, R. M. (1991). A motivational approach to self: Integration in personality. In R. Dienstbier (Ed.), Nebraska symposium on motivation, Vol. 38, Perspectives on motivation (pp. 237-288). Lincoln, NB: University of Nebraska Press.

Deci, E. L., \& Ryan, R. M. (2000). The "what" and "why" of goal pursuits: human needs and the self-determination of behavior. Psychological Inquiry, 11(4), 227 - 268.doi: 10.1207/S15327965PLI1104_01

Deci, E. L., \& Ryan, R. M. (2008). Self-determination theory: A macrotheory of human motivation, development, and health. Canadian Psychology/Psychologie canadienne, 49(3), 182 doi: 10.1037/a0012801

Diener, E., Emmons, R. A., Larsen, R. J., \& Griffin, S. (1985). The Satisfaction with Life Scale. Journal of Personality Assessment, 49, 71-75 doi:10.1207 s15327752jpa4901_13

Diener, E., Lucas, R. E., Oishi, S., \& Suh, E. M. (2002). Looking up and looking down: Weighting good and bad information in life satisfaction judgments. Personality and Social Psychology Bulletin, 28(4), 437-445.

Goodman, L. A. (1961). Snowball sampling. Annals of Mathematical Statistics, 32(1), 148170.

Hofmann, W., Luhmann, M., Fisher, R. R., Vohs, K. D., \& Baumeister, R. F. (2014). Yes, But Are They Happy? Effects of Trait Self-Control on Affective Well-Being and Life Satisfaction. Journal of Personality, 82(4), 265-277.

Joshanloo, M., \& Ghaedi, G. (2009). Value priorities as predictors of hedonic and eudaimonic aspects of well-being. Personality and Individual Differences, 47, 294298. doi:10.1016/j.paid.2009.03.016

Kasser, T. (2014). Teaching About Values and Goals: Applications of the Circumplex Modelto Motivation, Well-Being, and Prosocial Behavior. Teaching of Psychology, 41(4), 365-371. doi: 10.1177/0098628314549714 
Kasser, T., \& Ryan, R. M. (1993). A dark side of the American dream: correlates of financial success as a central life aspiration. Journal of personality and social psychology, 65(2), 410-422.

Kasser, T., \& Ryan, R. M. (1996). Further examining the American dream: Differential correlates of intrinsic and extrinsic goals. Personality and Social Psychology Bulletin 22, 280-287 doi:10.1177/0146167296223006

Kemppainen, T. (2012). Well-being in socio-political context: European welfare regimes in comparison. Helsinki: The Social Insurance Institution of Finland, Studies in social security and health 123 .

Lucas, R. E., Diener, E., \& Suh, E. (1996). Discriminant validity of well-being measures. Journal of Personality and Social Psychology, 71, 616-628.

Luhmann, M., Hawkley, L. C., Eid, M., \& Cacioppo, J. T. (2012). Time frames and the differences between affective and cognitive well-being. Journal of Research in Personality, 46, 431-441.

Marsh, H. W., \& Hocevar, D. (1985). Application of confirmatory factor analysis to the study of self-concept: first and higher-order factor models and their invariance across groups. Psychological Bulletin, 97, 562-582.

Novović, Z., \& Mihić, LJ. (2008). Serbian Inventory of Affect based on the Positive and Negative Affect Schedule-X. Unpublished manuscript. Novi Sad, University of Novi Sad [in Serbian]

Oishi, S., Diener, E., Suh, E. \& Lucas, R. E. (1999). Value as a moderator in subjective wellbeing. Journal of Personality, 67, 157-184. doi: 10.1111/1467-6494.00051

Pavlović, Z. (2006). Values in Serbia in the second era of modernism. Sociološki pregled, 40 (2), 247-262. doi:10.5937/socpreg0602247P [in Serbian]

Porter, M., Stern, S., \& Green, M. (2015). Social progress index 2015. Social progress imperative. Available at http://www.socialprogressimperative.org/system/resources/ W1siZiIsIjIwMTUvMDUvMDcvMTcvMjkvMzEvMzI4LzIwMTVfU09DSUFMX 1BST0dSRVNTX0lOREVYX0ZJTkFMLnBkZiJdXQ/2015\%20SOCIAL\%20PRO GRESS\%20INDEX_FINAL.pdf

Radović, O. (2014). Congruence with gender roles as a factor of subjective well-being in early adulthood. Doctoral dissertation. Belgrade: Faculty of Philosophy. [in Serbian]

Rijavec, M., Brdar, I., \& Miljković, D. (2011). Aspirations And Well-Being: Extrinsic Vs. Intrinsic Life Goals . Društvena Istraživanja, 693-710. doi:10.5559/di.20.3.05

Roccas, S., Sagiv, L., Schwartz, S. H., \& Knafo, A. (2002). The Big Five personality factors andpersonal values. Personality and Social Psychology Bulletin, 28, 789-801. doi: $10.1177 / 0146167202289008$

Sagiv, L., \& Schwartz, S. H. (2000). Values and subjective well-being: direct relations and congruity effects. European Journal of Social Psychology, 30, 177-198. doi: 10.1002 (SICI) 1099-0992(200003/04)30:2<177::AID-EJSP982>3.0.CO;2-Z

Sagiv, L., Roccas, S., \& Hazan, O. (2004). Value pathways to well-being: Healthy values, valued goal attainment, and environmental congruence. In: A. Linley, \& J. Stephen (Eds.), Positive Psychology in Practice. NJ: John Wiley.

Schmuck, P., Kasser, T. \& Ryan, R. M. (2000), Intrinsic and Extrinsic Goals: Their Structure and Relationship to Well-Being in German and U.S. College Students. Social Indicators Research, 50 (2), 225-241. 
Schumacker, R. E., \& Lomax, R. G. (2004). A beginner's guide to structural equation modeling, Second edition. Mahwah, NJ: Lawrence Erlbaum Associates.

Schwartz, S. H. (1992). A Proposal for Measuring Value Orientations across Nations. The Hebrew University of Jerusalem doi: 10.1016/S0065-2601(08)60281-6

Schwartz, S. H. (1994). Are there Universal Aspects in the Structure and Content of Human Values? Journal of Social Issues, 50, 19-45.

Schwartz, S. H. (2012). An Overview of the Schwartz Theory of Basic Values. Online Readings in Psychology and Culture, 2(1).http://dx.doi.org/10.9707/2307-0919.1116

Schwartz, S. H. (2014). Rethinking the concept and measurement of societal culture in light of empirical findings. Journal of cross-cultural Psychology, 45(1), 5-13.

Schwartz, S. H., Cieciuch, J.,Vecchione, M., Davidov, E., Fischer, R., Beierlein, C., Ramos, A., Verkasalo, M., Lönnqvist, J.-E., Demirutku, K., Dirilen-Gumus, O., \& Konty, M. (2012). Refining the theory of basic individual values. Journal of Personality and Social Psychology, 103(4), 663-688 doi: 10.1037/a0029393

Sortheix, F. M. (2014). Values and well-being in context: An analysis of country and group influences. Doctoral dissertation. University of Helsinki: Department of Social Research.

Sortheix, F. M., \& Lönnqvist J.-E. (2014). Personal value priorities and life satisfaction in Europe: The moderating role of socio-economic development. Journal of CrossCultural Psychology, 45, 282-299. doi: 10.1177/0022022113504621

Šuvaković, U. (2014). Transition, Contribution to Sociological Study of Social Changes. Kosovska Mitrovica: Faculty of Philosophy. [in Serbian]

Trotsuk, I.V. (2019). Three approaches to the sociological study of the social well-being. Sociološki pregled, vol. LIII (1), 80-99. doi: 10.5937/socpreg53-20845

United Nations Development Programme (2015). Human Development Report 2015 Work for Human Development, New York: UNDP, retrieved from http://hdr.undp org/sites/default/files/2015_human_development_report.pdf, on 23.01.2017.

Uvalić, M. (2010). Serbia's Transition: Toward a Better Future, UK: Palgrave Macmillan, doi: $10.1057 / 9780230281745$

Wheaton, B., Muthen, B., Alwin, D., F., \& Summers, G. (1977). Assessing Reliability and Stability in Panel Models. Sociological Methodology, 8(1), 84-136. 
Оливера Б. Радовић, Драгана 3. Станојевић, Оливер М. Тошковић, Вреgностии и...

\section{APPENDIX / ПРИЛОЗИ}

Табела 1. 19 вредности у ревидираној теорији, свака дефинисана у погледу свог мотивационог циља (Schwartz et al., 2012). Репродуковано са дозволом./

Table 1 . The 19 values in the refined theory, each defined in terms of its motivational goal (Schwartz et al., 2012). Reproduced with permission.

\begin{tabular}{|c|c|}
\hline Вредност/Value & $\begin{array}{l}\text { Концептуалне дефиниције у погледу мотивационих } \\
\text { циљева/ } \\
\text { Conceptual definitions in terms of motivational goals }\end{array}$ \\
\hline $\begin{array}{l}\text { Самоусмерење- мисао/ } \\
\text { Self-direction-thought }\end{array}$ & $\begin{array}{l}\text { Слобода култивисања сопствених идеја и } \\
\text { способности/ } \\
\text { Freedom to cultivate one's own ideas and abilities }\end{array}$ \\
\hline $\begin{array}{l}\text { Самоусмерење - } \\
\text { делање/ } \\
\text { Self-direction-action }\end{array}$ & $\begin{array}{l}\text { Слобода одређивања властитих поступака/ } \\
\text { Freedom to determine one's own actions }\end{array}$ \\
\hline $\begin{array}{l}\text { Стимулација/ } \\
\text { Stimulation }\end{array}$ & $\begin{array}{l}\text { Узбуђење, новина и промена/ } \\
\text { Excitement, novelty, and change }\end{array}$ \\
\hline Хедонизам/ Hedonism & $\begin{array}{l}\text { Ужитак и чулно задовољство/ } \\
\text { Pleasure and sensuous gratification }\end{array}$ \\
\hline $\begin{array}{l}\text { Постигнуће/ } \\
\text { Achievement }\end{array}$ & $\begin{array}{l}\text { Успех према друштвеним стандардима/ } \\
\text { Success according to social standards }\end{array}$ \\
\hline $\begin{array}{l}\text { Мoћ-доминација/ } \\
\text { Power-dominance }\end{array}$ & $\begin{array}{l}\text { Моћ кроз вршење контроле над људима/ } \\
\text { Power through exercising control over people }\end{array}$ \\
\hline $\begin{array}{l}\text { Moћ-ресурси/ } \\
\text { Power-resources }\end{array}$ & $\begin{array}{l}\text { Моћ кроз контролу материјалних и друштвених } \\
\text { ресурса/ } \\
\text { Power through control of material and social resources }\end{array}$ \\
\hline Имиџ/ Face & $\begin{array}{l}\text { Сигурност и моћ кроз одржавање јавног имиџа и } \\
\text { избегавање понижења/ } \\
\text { Security and power through maintaining one's public } \\
\text { image and avoiding humiliation }\end{array}$ \\
\hline $\begin{array}{l}\text { Сигурност-лична/ } \\
\text { Security-personal }\end{array}$ & $\begin{array}{l}\text { Сигурност у непосредном окружењу/ } \\
\text { Safety in one's immediate environment }\end{array}$ \\
\hline $\begin{array}{l}\text { Сигурност-друштвена/ } \\
\text { Security-societal }\end{array}$ & $\begin{array}{l}\text { Сигурност и стабилност у ширем друштву/ } \\
\text { Safety and stability in the wider society }\end{array}$ \\
\hline Традиција/Tradition & $\begin{array}{l}\text { Одржавање и очување културне, породичне или } \\
\text { верске традиције/ } \\
\text { Maintaining and preserving cultural, family, or religious } \\
\text { traditions }\end{array}$ \\
\hline
\end{tabular}




\begin{tabular}{|c|c|}
\hline $\begin{array}{l}\text { Конформизам } \\
\text {-правила/ } \\
\text { Conformity-rules }\end{array}$ & $\begin{array}{l}\text { Усклађеност са правилима, законима и формалним } \\
\text { обавезама/ } \\
\text { Compliance with rules, laws, and formal obligations }\end{array}$ \\
\hline $\begin{array}{l}\text { Конформизам- } \\
\text { међуљудски/ } \\
\text { Conformity-interper- } \\
\text { sonal }\end{array}$ & $\begin{array}{l}\text { Избегавање узнемиравања или наношења штете } \\
\text { другим људима/ } \\
\text { Avoidance of upsetting or harming other people }\end{array}$ \\
\hline Понизност/ Humility & $\begin{array}{l}\text { Препознавање сопствене неважности у већој шеми } \\
\text { ствари/ } \\
\text { Recognizing one's insignificance in the larger scheme } \\
\text { of things }\end{array}$ \\
\hline $\begin{array}{l}\text { Човекољубље } \\
\text {-поузданост/ } \\
\text { Benevolence-depend- } \\
\text { ability }\end{array}$ & $\begin{array}{l}\text { Бити поуздан члан групе/ } \\
\text { Being a reliable and trustworthy member of the in- } \\
\text { group }\end{array}$ \\
\hline $\begin{array}{l}\text { Човекољубље - } \\
\text { брижност/ } \\
\text { Benevolence-caring }\end{array}$ & $\begin{array}{l}\text { Преданост добробити чланова групе/ } \\
\text { Devotion to the welfare of ingroup members }\end{array}$ \\
\hline $\begin{array}{l}\text { Универзализам-брига/ } \\
\text { Universalism-concern }\end{array}$ & $\begin{array}{l}\text { Посвећеност једнакости, правди и заштити свих } \\
\text { људи/ } \\
\text { Commitment to equality, justice, and protection for all } \\
\text { people }\end{array}$ \\
\hline $\begin{array}{l}\text { Универзализам- } \\
\text { природа/ } \\
\text { Universalism-nature }\end{array}$ & $\begin{array}{l}\text { Очување природног окружења/ } \\
\text { Preservation of the natural environment }\end{array}$ \\
\hline $\begin{array}{l}\text { Универзализам- } \\
\text { толеранција/ } \\
\text { Universalism-tolerance }\end{array}$ & $\begin{array}{l}\text { Прихватање и разумевање оних који су } \\
\text { различити/ } \\
\text { Acceptance and understanding of those who } \\
\text { are different from oneself }\end{array}$ \\
\hline
\end{tabular}


Оливера Б. Радовић, Драгана 3. Станојевић, Оливер М. Тошковић, Вреgностии и...

Табела 2. Конфирматорна факторска анализа за сваки фактор вишег реда: Отвореност за промене, Самоусавршавање, Самопревазилажење и Очување/

Table 2. The confirmatory factor analyses ${ }^{\star}$ for every higher order factor: Openness to change, Self-enhancement, Self-transcendence, and Conservation

\begin{tabular}{|l|c|c|c|c|c|}
\hline $\begin{array}{l}\text { Ниво инваријантности } \\
\text { /Level of invariance }\end{array}$ & $\chi^{2}$ & $\mathrm{df}$ & $\mathrm{CFI}$ & $\mathrm{RMSEA}$ & $\mathrm{X}^{2} / \mathrm{df}$ \\
\hline Отвореност/Openness & 53.069 & 48 & .984 & .016 & 1.11 \\
\hline Очување/Conservation & 151.445 & 168 & .999 & .000 & 0.90 \\
\hline $\begin{array}{l}\text { Самоусавршавање/ } \\
\text { Self-enhancement }\end{array}$ & 26.266 & 24 & .988 & .015 & 1.09 \\
\hline $\begin{array}{l}\text { Cамопревазилажење/ } \\
\text { Self-transсеndence }\end{array}$ & 93.201 & 80 & .968 & .020 & 1.17 \\
\hline
\end{tabular}

* Сирови резултати/ Raw value scores

Табела 3. Средње и стандардно одступање променљивих/

Table 3. Mean and Standard Deviation of Variables*

\begin{tabular}{|c|c|c|c|c|c|c|c|c|}
\hline & $\mathrm{N}$ & $\begin{array}{c}\text { Мин/ } \\
\text { Min }\end{array}$ & $\begin{array}{c}\text { Макс/ } \\
\text { Max }\end{array}$ & $\begin{array}{c}\text { Средња/ } \\
\text { Mean }\end{array}$ & $\begin{array}{c}\text { Стд. } \\
\text { девијација/ } \\
\text { Std. } \\
\text { Deviation }\end{array}$ & $\begin{array}{c}\text { Ранг } \\
\text { /Rank }\end{array}$ & $\begin{array}{l}\text { Скјунес/ } \\
\text { Skewness }\end{array}$ & $\begin{array}{c}\text { Куртозис } \\
\text { Kurtosis }\end{array}$ \\
\hline $\begin{array}{c}\text { Доброчинство- } \\
\text { поузданост/ } \\
\text { Benevolence-de- } \\
\text { pendability }\end{array}$ & 410 & $\mid-0.88$ & 2.21 & 0.9 & 0.57 & 1 & -0.59 & 0.22 \\
\hline $\begin{array}{c}\text { Доброчинство- } \\
\text { брижност/ } \\
\text { Benevolence-caring }\end{array}$ & 409 & -0.95 & 2.35 & 0.88 & 0.55 & 2 & -0.27 & -0.03 \\
\hline $\begin{array}{l}\text { Самоусмерење- } \\
\text { делање/ } \\
\text { Self-direction- } \\
\text { action }\end{array}$ & 411 & -2.51 & 2.58 & 0.62 & 0.66 & 3 & -0.67 & 1.85 \\
\hline $\begin{array}{c}\text { Универзализам- } \\
\text { брига/ } \\
\text { Universalism- } \\
\text { concern }\end{array}$ & 408 & $\mid-1.47$ & 2 & 0.53 & 0.6 & 4 & -0.38 & 0.14 \\
\hline
\end{tabular}


Социолошки ӥреїлеg, vol. LIII (2019), nо. 3, стр. 908-942

\begin{tabular}{|c|c|c|c|c|c|c|c|c|}
\hline $\begin{array}{c}\text { Самоусмерење- } \\
\text { мисао/ } \\
\text { Self-direction- } \\
\text { thought }\end{array}$ & 408 & -2.11 & 2.6 & 0.51 & 0.68 & 5 & -0.26 & 0.23 \\
\hline $\begin{array}{c}\text { Сигурност-лична/ } \\
\text { Security-personal }\end{array}$ & 409 & $\mid-1.86$ & 2.26 & 0.4 & 0.67 & 6 & -0.55 & 0.68 \\
\hline $\begin{array}{c}\text { Сигурност- } \\
\text { друштвена/ } \\
\text { Security-societal }\end{array}$ & 409 & $\mid-2.61$ & 2.28 & 0.37 & 0.83 & 7 & -0.72 & 0.88 \\
\hline $\begin{array}{l}\text { Постигнуће/ } \\
\text { Achievement }\end{array}$ & 407 & -2.68 & 1.88 & 0.31 & 0.65 & 8 & -0.64 & 1.24 \\
\hline $\begin{array}{c}\text { Универзализам- } \\
\text { толеранција/ } \\
\text { Universalism-toler- } \\
\text { ance }\end{array}$ & 409 & $\mid-2.21$ & 1.74 & 0.25 & 0.69 & 9 & -0.69 & 0.79 \\
\hline $\begin{array}{l}\text { Традиција/ } \\
\text { Tradition }\end{array}$ & 411 & $\mid-3.21$ & 2.14 & 0.19 & 0.97 & 10 & -0.9 & 0.84 \\
\hline Имиџ/ Face & 405 & -2.53 & 2.02 & 0.08 & 0.75 & 11 & -0.53 & 0.22 \\
\hline $\begin{array}{l}\text { Хедонизам/ } \\
\text { Hedonism }\end{array}$ & 410 & -2.98 & 2.6 & -0.05 & 0.94 & 12 & -0.5 & 0.3 \\
\hline $\begin{array}{c}\text { Конформизам- } \\
\text { међуљудски/ } \\
\text { Conformity-inter- } \\
\text { personal }\end{array}$ & 408 & $\mid-3.19$ & 1.81 & -0.12 & 0.85 & 13 & -0.45 & 0.19 \\
\hline $\begin{array}{c}\text { Универзализам - } \\
\text { природа/ } \\
\text { Universalism-nature }\end{array}$ & 407 & $\mid-3.19$ & 1.86 & -0.19 & 0.93 & 14 & -0.34 & -0.06 \\
\hline $\begin{array}{l}\text { Стимулација/ } \\
\text { Stimulation }\end{array}$ & 409 & $\mid-3.14$ & 2.35 & -0.26 & 0.93 & 15 & -0.33 & 0.1 \\
\hline $\begin{array}{l}\text { Конформизам- } \\
\text { правила/ } \\
\text { Conformity-rules }\end{array}$ & 410 & $\mid-4.25$ & 2.04 & -0.36 & 0.95 & 16 & -0.58 & 0.34 \\
\hline $\begin{array}{c}\text { Понизност/ } \\
\text { Humility }\end{array}$ & 409 & $\mid-3.98$ & 1.33 & -1.03 & 0.9 & 17 & -0.15 & 0.39 \\
\hline
\end{tabular}


Оливера Б. Радовић, Драгана 3. Станојевић, Оливер М. Тошковић, Вреgностии и...

\begin{tabular}{|c|c|c|c|c|c|c|c|c|}
\hline $\begin{array}{c}\text { Мoћ-ресурси/ } \\
\text { Power-resources }\end{array}$ & 411 & -4.25 & 2.35 & -1.41 & 1.14 & 18 & 0.18 & -0.28 \\
\hline $\begin{array}{c}\text { Моћ-доминација/ } \\
\text { Power-dominance }\end{array}$ & 407 & -4.23 & 2.35 & -1.42 & 1.15 & 19 & 0.14 & -0.31 \\
\hline
\end{tabular}

* Центриране вредности/ Centered value scores

Табела 4. Корелације 19 типова вредности са индексима субјективне добробити/ Table 4. Correlations ${ }^{\star}$ of 19 value types with indexes of SWB

\begin{tabular}{|c|c|c|c|}
\hline & $\begin{array}{c}\text { Задовољство } \\
\text { животом/ } \\
\text { Satisfaction with } \\
\text { life }\end{array}$ & $\begin{array}{c}\text { Позитиван } \\
\text { афекат/ } \\
\text { Positive Affect }\end{array}$ & $\begin{array}{c}\text { Негативан } \\
\text { афекат/ } \\
\text { Negative } \\
\text { Affect }\end{array}$ \\
\hline $\begin{array}{l}\text { Самоусмерење-мисао/ } \\
\text { Self-direction-thought }\end{array}$ & .046 & $.199^{* *}$ & -.073 \\
\hline $\begin{array}{l}\text { Самоусмерење-делање/ } \\
\text { Self-direction-actiom }\end{array}$ & .035 & $.145^{* *}$ & -.092 \\
\hline $\begin{array}{l}\text { Стимулација/ } \\
\text { Stimulation }\end{array}$ & .056 & $.157^{* *}$ & -.007 \\
\hline Хедонизам/ Hedonism & .064 & -.018 & -.022 \\
\hline Постигнуће/ Achievement & $.184^{* *}$ & $.230^{* *}$ & $-.139^{* *}$ \\
\hline $\begin{array}{l}\text { Moћ-доминација/ } \\
\text { Power-dominance }\end{array}$ & .002 & -.097 & $.159^{* *}$ \\
\hline $\begin{array}{l}\text { Moћ-ресурси/ } \\
\text { Powep-resources }\end{array}$ & -.093 & $-.120^{*}$ & $.170^{* *}$ \\
\hline Имиџ/ Face & $-.116^{*}$ & -.024 & -.094 \\
\hline $\begin{array}{l}\text { Сигурност-лична/ } \\
\text { Security-personal }\end{array}$ & -.089 & -.068 & -.002 \\
\hline $\begin{array}{l}\text { Сигурност-друштвена/ } \\
\text { Security-societal }\end{array}$ & -.075 & -.026 & .010 \\
\hline Традиција/Tradition & -.042 & -.057 & -.057 \\
\hline
\end{tabular}




\begin{tabular}{|c|c|c|c|}
\hline Понизнист/ Humility & -.070 & $-.213^{* *}$ & $.098^{*}$ \\
\hline $\begin{array}{l}\text { Конформизам-правила/ } \\
\text { Conformity-rules }\end{array}$ & $.108^{*}$ & .029 & .025 \\
\hline $\begin{array}{l}\text { Конформизам-међуљудски/ } \\
\text { Conformity-interpersonal }\end{array}$ & -.087 & $-.139^{* *}$ & .071 \\
\hline $\begin{array}{l}\text { Универзализам-природа/ } \\
\text { Universalism-nature }\end{array}$ & -.082 & .068 & -.020 \\
\hline $\begin{array}{l}\text { Универзализам-брига/ } \\
\text { Universalism-concern }\end{array}$ & .039 & -.042 & -.022 \\
\hline $\begin{array}{l}\text { Универзализам- } \\
\text { толеранција/ } \\
\text { Universalism-tolerance }\end{array}$ & $.148^{* *}$ & .039 & .051 \\
\hline $\begin{array}{l}\text { Човекољубље-брижност/ } \\
\text { Benevolence-caring }\end{array}$ & .069 & .090 & $-.144^{* *}$ \\
\hline $\begin{array}{l}\text { Човекољубље- } \\
\text { поузданост/ } \\
\text { Benevolence-dependability }\end{array}$ & .034 & $.099^{*}$ & $-.208^{* *}$ \\
\hline
\end{tabular}

* Центриране вредности / Centered value scores Hайомена/ Note. ${ }^{*} p<.05 ;{ }^{* *} p<.01$.

Табела 5. Каноничка корелациона анализа - факторска значајност и оптерећења/ Table 5. Canonical correlation analysis ${ }^{*}$ - factor significance and loadings

\begin{tabular}{|c|c|c|c|c|}
\hline & & $\begin{array}{c}\text { Канонички фактор 1/ } \\
\text { Canonical factor 1 }\end{array}$ & $\begin{array}{c}\text { Канонички фактор 2/ } \\
\text { Canonical factor 2 }\end{array}$ \\
\hline & $\begin{array}{c}\left(\mathrm{Rho}=.59 ; \mathrm{X}^{2}(57)=227.97 ;\right. \\
\mathrm{p}<0.01)\end{array}$ & $\begin{array}{c}\left(\mathrm{Rho}=.41 ; \mathrm{X}^{2}(36)=81.11 ;\right. \\
\mathrm{p}<0.01)\end{array}$ \\
\hline $\begin{array}{c}\text { обjашњена вapиjaнca/ vari- } \\
\text { ance explained }\end{array}$ & 0.197 & 0.053 \\
\hline & $\begin{array}{c}\text { Camoycmepeњe- } \\
\text { mucao/ } \\
\text { Self-direction- } \\
\text { thought }\end{array}$ & .691 & -.235 \\
\hline
\end{tabular}


Оливера Б. Радовић, Драгана 3. Станојевић, Оливер М. Тошковић, Вреgностии и...

\begin{tabular}{|c|c|c|c|}
\hline \multirow{13}{*}{ 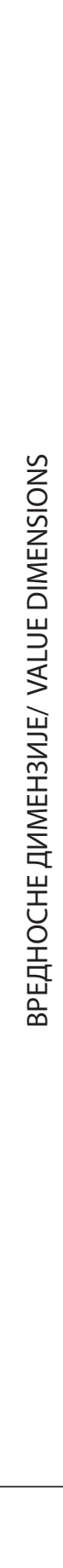 } & $\begin{array}{c}\text { Самоусмерење- } \\
\text { делање/ } \\
\text { Self-direction- } \\
\text { action }\end{array}$ & .625 & -.281 \\
\hline & $\begin{array}{l}\text { Стимулација/ } \\
\text { Stimulation }\end{array}$ & .576 & -.170 \\
\hline & $\begin{array}{l}\text { Хедонизам/ } \\
\text { Hedonism }\end{array}$ & .427 & .044 \\
\hline & $\begin{array}{l}\text { Постигнуће/ } \\
\text { Achievement }\end{array}$ & .704 & -.212 \\
\hline & $\begin{array}{c}\text { Мoћ- } \\
\text { доминација/ } \\
\text { Power-domi- } \\
\text { nance }\end{array}$ & .249 & .357 \\
\hline & $\begin{array}{l}\text { Moћ-ресурси/ } \\
\text { Power-resources }\end{array}$ & .147 & .210 \\
\hline & Имиџ/ Face & .247 & -.277 \\
\hline & $\begin{array}{c}\text { Сигурност- } \\
\text { лична/ Security- } \\
\text { personal }\end{array}$ & .273 & -.105 \\
\hline & $\begin{array}{c}\text { Сигурност- } \\
\text { друштвена/ } \\
\text { Security-societal }\end{array}$ & .236 & -.171 \\
\hline & $\begin{array}{l}\text { Традиција/ } \\
\text { Tradition }\end{array}$ & .184 & -.134 \\
\hline & $\begin{array}{c}\text { Конформизам- } \\
\text { правила/ } \\
\text { Conformity-rules }\end{array}$ & .447 & .132 \\
\hline & $\begin{array}{c}\text { Конформизам- } \\
\text { међуљудски/ } \\
\text { Conformity-inter- } \\
\text { personal }\end{array}$ & .198 & .089 \\
\hline & $\begin{array}{c}\text { Понизност/ } \\
\text { Humility }\end{array}$ & .098 & .351 \\
\hline
\end{tabular}




\begin{tabular}{|c|c|c|c|}
\hline & $\begin{array}{c}\text { Универзализам- } \\
\text { природа/ } \\
\text { Universalism- } \\
\text { nature }\end{array}$ & .298 & -.239 \\
\hline & $\begin{array}{c}\text { Универзализам- } \\
\text { брига/ Universal- } \\
\text { ism-concern }\end{array}$ & .462 & .103 \\
\hline & $\begin{array}{c}\text { Универзализам- } \\
\text { толеранција/ } \\
\text { Universalism- } \\
\text { tolerance }\end{array}$ & .581 & .268 \\
\hline & $\begin{array}{c}\text { Човекољубље- } \\
\text { брижност/ } \\
\text { Benevolence- } \\
\text { caring }\end{array}$ & .599 & -.244 \\
\hline & $\begin{array}{c}\text { Човекољубље- } \\
\text { поузданост/ } \\
\text { Benevolence- } \\
\text { dependability }\end{array}$ & .553 & -.376 \\
\hline \multicolumn{2}{|c|}{$\begin{array}{c}\text { објашњена варијанса/ vari- } \\
\text { ance explained }\end{array}$} & 0.509 & 0.247 \\
\hline \multirow{3}{*}{ 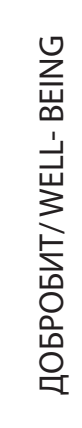 } & $\begin{array}{c}\text { Негативан } \\
\text { афекат/ Negative } \\
\text { Affect }\end{array}$ & -.286 & .652 \\
\hline & $\begin{array}{c}\text { Позитиван } \\
\text { афекат/ Positive } \\
\text { Affect }\end{array}$ & .858 & -.442 \\
\hline & $\begin{array}{c}\text { Задовољство } \\
\text { животом/ Satis- } \\
\text { faction of life }\end{array}$ & .842 & .347 \\
\hline
\end{tabular}

* Сирови резултати/ Raw value scores

Напомена: значајна оптерећења су подебљана. / Note.significant loadings are in bold 
Оливера Б. Радовић, Драгана 3. Станојевић, Оливер М. Тошковић, Вреgностии и...

Слика 1. Дијаграм пута за фактор вишег реда Отвореност, са стандардизованим вредностима оптерећења

Figure 1. Path diagram for higher order factor Openness, with standardized loading values

НАЗАД

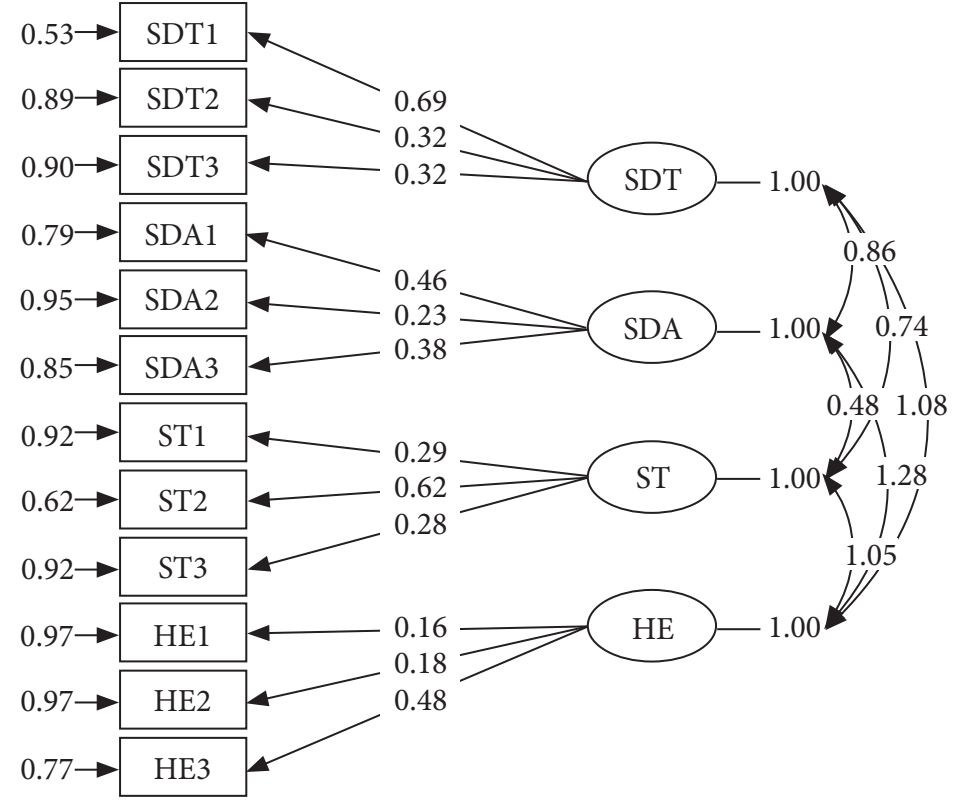


Слика 2. Дијаграм пута за фактор вишег реда Очување, са стандардизованим вредностима оптерећења

Figure 2. Path diagram for higher order factor Conservation, with standardized loading values

НАЗАД

BACK

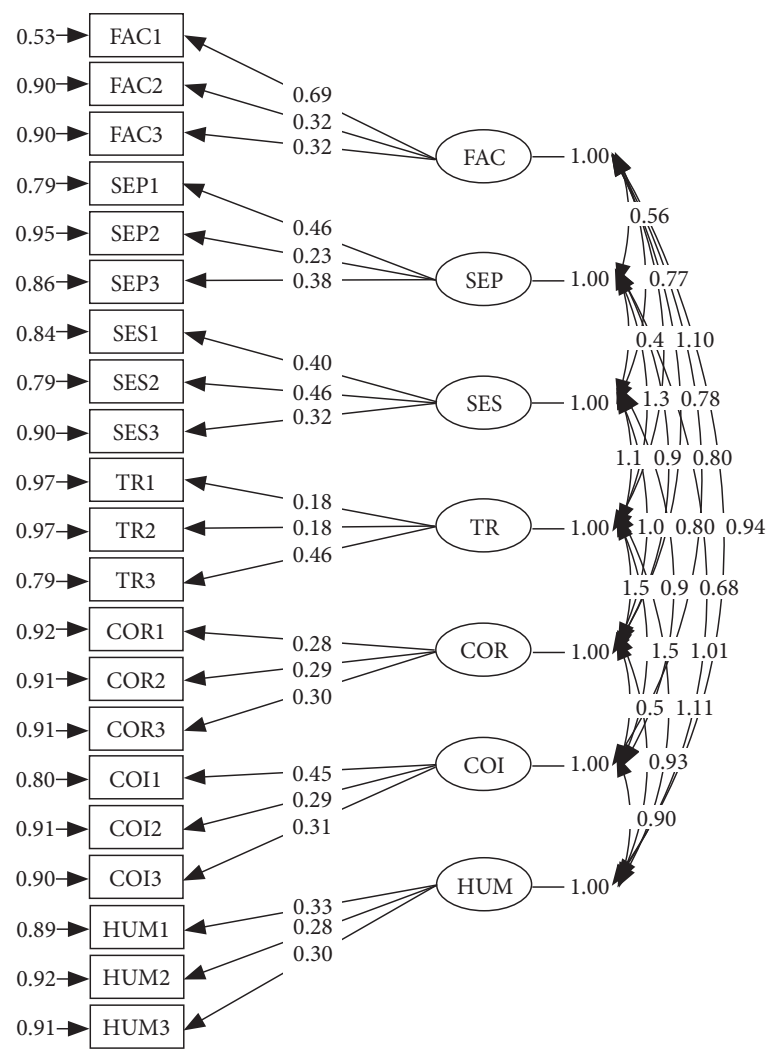

Слика 3. Дијаграм пута за фактор вишег реда Самоусавршавање, са стандардизованим вредностима оптерећења

Figure 3. Path diagram for higher order factor Self-enhancement, with standardized

НАЗАД

BACK loading values

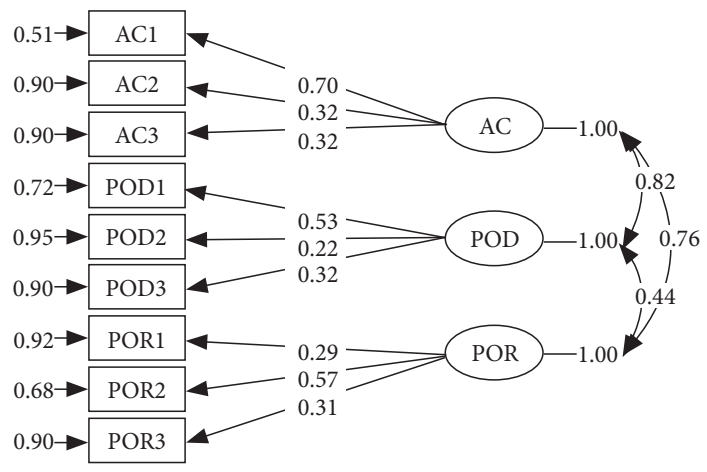


Оливера Б. Радовић, Драгана 3. Станојевић, Оливер М. Тошковић, Вреgностии и...

Слика 4. Дијаграм пута за фактор вишег реда Самопревазилажење, са стандардизованим вредностима оптерећења

Figure 4. Path diagram for higher order factor Self-transcendence, with standardized loading values

НАЗАД

BACK

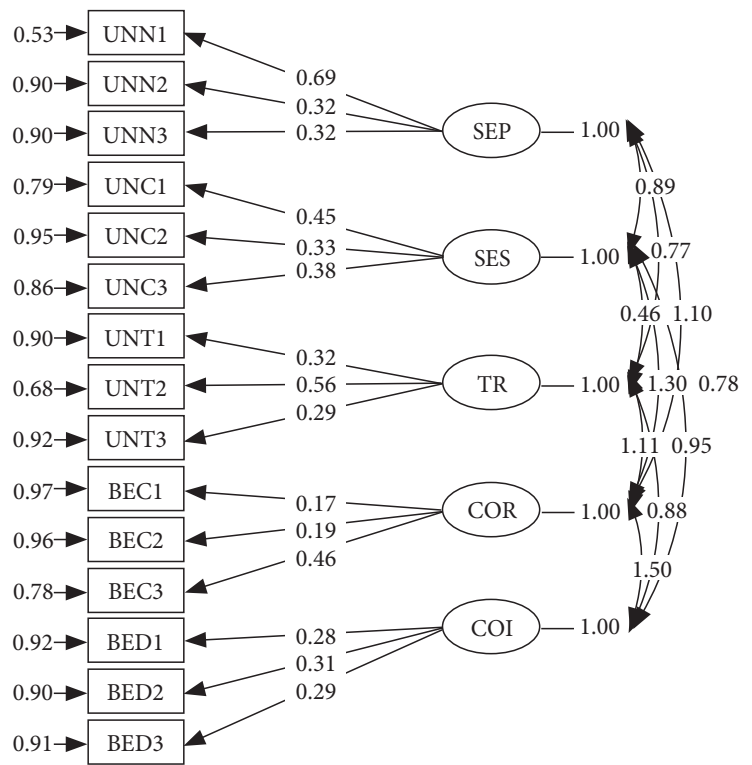

Слика 5. Мултидимензионална анализа скалирања 57 ајтема на индексима центриране вредности. N_412, Stress 1_.176, DAF $=.969$, ТCC $=.984$

Figure 5. Multidimensional scaling analysis of 57 items on centered value indexes. N_412, Stress $1 \_.176, \mathrm{DAF}=.969, \mathrm{TCC}=.984$

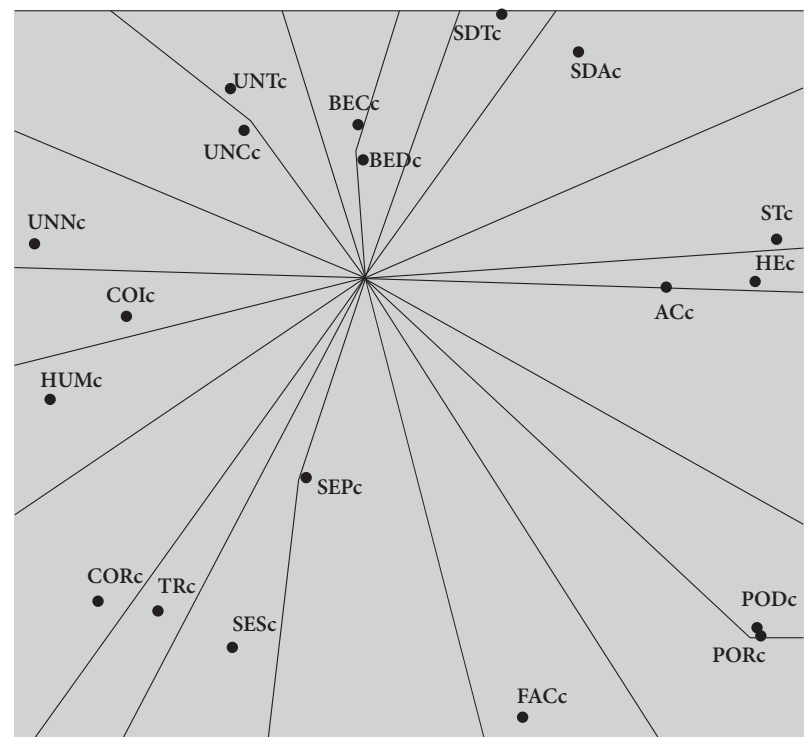

